\title{
The Myth of Judicial Supervision in Three "Inquisitorial" Systems: France, Italy, and Germany*
}

\author{
Abraham S. Goldstein ${ }^{\dagger}$ and Martin Marcus ${ }^{\dagger}$
}

American criminal justice is characterized by the broad discretion of police and prosecutor and by an overwhelming reliance on the guilty plea. Discretion is said to be both inevitable and desirable, especially when it is exercised by the prosecutor. ${ }^{1}$ Through his power to determine the number and nature of criminal charges, the prosecutor is able to manage a heavy caseload with existing resources, to reconcile general criminal statutes with mitigating factors in particular cases, and to establish priorities among offenders, offenses, and law enforcement strategies. The principal mechanism that enables the prosecutor to achieve these objectives, and to gain the defendant's cooperation in doing so, is the guilty plea. Especially in "plea bargaining" and in the dismissals and charge reductions associated with it, prosecutor and defendant are said to join in minimizing contentiousness and improving "the quality of justice" by limiting trials to "real disputes."2

A rich body of literature has demonstrated that criminal laws are regularly stretched or disregarded by police and prosecutors as they

* Copyright (C) 1977 by Abraham S. Goldstein. The research for this article was supported in part by a grant from the National Science Foundation. Much of it was written during the period in 1975-76 when A. Goldstein was a Guggenheim Fellow. The authors are deeply grateful to the following persons for their generous assistance in arranging interviews and in providing advice and criticism. The conclusions, however, are those of the authors. In Italy: Rome-Peter Alegi, Esq., of Baker \& McKenzie; Guisseppe di Gennaro, Justice of the Supreme Court of Cassation; Dr. Eduardo Vetere, Criminal Justice Section, United Nations Secretariat; Perugia-Dr. S. Zaganelli, Adrocate; FlorenceProfessors Vincenzo Varano, Vincenzo Vigoriti, and Mauro Cappelletti of the Institute of Comparative Law, University of Florence. In Germany: Professor Joachim Herrmann and his assistant, Herr Decker, University of Augsburg; Professor Hans-Heinrich Jescheck and Dr. Thomas Wiegand of the Max Planck Institute of Foreign and Comparative Criminal Law, Freiburg. In France: Clifford Michel, Esq., and Mme. Christine Agasse of Cahill, Gordon \& Reindel, Paris; M. Jacques Verin, Director of Research, French Ministry of Justice.

+ Sterling Professor of Law, Yale Law School.

+ Research Fellow, Yale Law School, 1975-76. Member, New York Bar.

1. For historical background, see Miller, The Compromise of Criminal Cases, $1 \mathrm{~S}$. Cal. L. Rev. 1, 1-2 (1927) (cases and discussion); Comment, The Plea Bargain in Historical Perspective, 23 Buffalo L. Rev. 499, 512-24 (1974).

2. ABa Standards Relating to Pleas of Gullty 2-3 (1968). 
choose among the crimes to be investigated and charged. ${ }^{3}$ Prosecutors accept pleas to lesser offenses because strict application of the law would produce too harsh a result. Charges are reduced, dismissed, or not brought at all in return for cooperation from a defendant or a potential defendant that will facilitate the conviction of another, more culpable offender. $\$$ Particularly as the volume of crime increases and offense categories proliferate, even serious crimes are not fully prosecuted because it might be unduly time consuming to conduct a full investigation or to defend a search or confession against a claim of illegality.

The existence of so many choices, and so few guides for making them, makes it inevitable not only that the criminal law be applied unevenly, but also that the common image of law enforcement as arbitrary and manipulable be reinforced. The public cannot learn whether or not criminals are "getting away with it," and the courtsperhaps even the defendants-may not know what evidentiary weaknesses or procedural irregularities are concealed behind the prosecutor's offers. These concerns have led to a virtual consensus that discretion and guilty pleas must be brought into the open and dealt with directly. A variety of measures has been suggested. ${ }^{5}$ Some have proposed that the

3. Some statutes might have been read to require prosecution whenever there was sufficient evidence. E.g., 28 U.S.C. $\$ 547$ (1970): "Except as otherwise provided by law, each United States attorney, within his district, shall-(1) prosecute for all offenses against the United States ...."

But such statutes have been interpreted as imposing a discretionary rather than a ministerial duty on the prosecutor. E.g., In re Confiscation Cases, 74 U.S. 454, 457 (1868); United States v. Cox, 342 F.2d 167, 171 (5th Cir.), cert. denied, 381 U.S. 935 (1965); Fay v. Miller, 183 F.2d 986, 988 (D.C. Cir. 1959); Pugach v. Klein, 193 F. Supp. 630, 633-35 (S.D.N.Y. 1961); People ex rel. Hanrahan v. One 1965 Oldsmobile, 52 Ill. 2d 37, 43, 284 N.E.2d 646, 65l, rev'd on other grounds sub nom. Robinson v. Hanrahan, 408 U.S. 38 (1972); Leone v. Fanelli, 194 Misc. 826, 827, 87 N.Y.S.2d 850, 851 (1949). See also People v. Vatelli, 15 Cal. App. 3d 54, 58, 92 Cal. Rptr. 763, 765 (1971); Note, Prosecutor's Discretion, 103 U. PA. L. REv. 1057,1058 (1955).

4. See generally D. Newman, Conviction (1966); D. MIClNtyre, Law Enforcement in the Metropolis 132.35 (1967); F. Miller, Prosecution (1969); Vera Institute of Justice, Felony ArRests: Their Prosecution and Disposition in New York City's Courts (1977); Alschuler, The Trial Judge's Role in Plea Bargaining, Part $I, 76$ Colum. L. Rev. 1059 (1976); Alschuler, The Defense Attorney's Role in Plea Bargaining, 84 YALE L.J. 1179 (1975); Alschuler, The Prosecutor's Role In Plea Bargaining, 36 U. CHI. L. REv. 50 (1968).

5. See generally K. Davis, Discretionary Justice (1969). See also ABA Standards Relating to the Prosecution Function and the Defense Function 64-66, 83-87, 92-98, 102-10 (1971); ABA Standards Reiating to Pleas of Guilty 60-78 (1968); President's Commission on Law Enforcemint and Adimisiration of Justice, Task Force Report: The Courts 7-13 (1967); President's CoMmission on Law ENForCEMent and AdministratION OF JUSTICE, TASK FORCE REPORT: THE POLICE 18-27 (1967); Abrams, Internal Policy: Guiding the Exercise of Prosecutorial Discretion, 19 U.C.L.A. L. REv. 1 (1971); J. Goldstein, Police Discretion Not to Invoke the Criminal Process: Low-Trisibility Decisions in the Administralion of Justice, 69 YALE L.J. 543 (1960). 
investigative and charging authority of police and prosecutor be more strictly limited; others would have them issue rules defining the standards for exercising their discretion and would subject those standards and their application in individual cases to judicial review. Still others would bring charging policies, dismissals, and plea arrangements under more direct judicial supervision. ${ }^{6}$

Underlying these proposals and reforms is an emerging concern that American law has been too casual in addressing these matters-that disposition by agreement of the parties may intrude upon legislative and judicial functions and that the concept of "inherent" prosecutorial discretion may be inconsistent with the rule of law. Responding to these concerns, commentators are turning their attention to the so-called inquisitorial systems of the Western European nations. The literature describing many of those systems suggests that the problems now facing us, and provoking so much controversy, may already have been solved in those countries. ${ }^{7}$ In Germany, it is commonly asserted that the

6. The courts have begun to respond to these suggestions, drawing on the considerable body of law regulating police investigation. In cases dealing with selective prosecution, dismissals, and guilty pleas, judges are intervening more often in the charging process. Significantly, the taking of a plea-once a perfunctory ritual-is becoming the occasion for a substantial judicial inquiry into the factual basis of the defendant's guilt, the inducements offered, the voluntariness of his decision, and his understanding of its consequences. See generally A. Goldstein, Reflections on Two Models: Inquisitorial Themes in American Criminal Procedure, 26 Stan. L. Rev. 1009, 1022-24 (1974). On guilty pleas, see McCarthy v. United States, 394 U.S. 459 (1969); on dismissals, see United States v. Cowan, 524 F.2d 504 (5th Cir. 1975), cert. denied, 425 U.S. 971 (1976); United States v. Ammidlown, 497 F.2d 615 (D.C. Cir. 1973); on selective prosecution, see United States v. Falk, 479 F.2d 616 (7th Cir. 1973) (en banc).

7. For a general introduction to the distinction between accusatorial and inquisitorial systems, see P. Howard, Criminal Justice in England, 381-94 (1931); Damaska, Evidentiary Barriers to Conviction and Two Models of Criminal Procedure: $A$ Comparative Study, 121 U. PA. L. REv. 506 (1973); A. Goldstein, supra note 6, at 1015-21. For historical background, see J. Langbein, Prosecuting, Crime in rhe Rexaissance 130-34 (1974); Ploscowe, The Development of Present-Day Criminal Procedures in Europe and America, 48 HaRv. L. REv. 433 (1935).

We use the term "inquisitorial" to describe a system in which the state, rather than the parties, has the overriding responsibility for eliciting the facts of the crime. In its pure form, the judge discharges that responsibility, both before and at trial. There are many variations. For example, the public prosecutor may substitute for or share with the judge the responsibility for pretrial investigation. But everywhere the judge is expected to carry the factfinding initiative at trial, using the file (dossier) prepared during the pretrial investigation by an examining judge (or magistrate) or public prosecutor. Some have suggested that the judge's role in questioning the defendant and witnesses at trial is the most distinctive feature of the system. See G. Williams, The Proof of Gullt 29 (1963); Langbein, Controlling Proseculorial Discretion in Germany, 41 U. CHI. L. REv. 439, 446-47 (1974) [hereinafter cited as Prosecutorial Discretion].

Europeans often refer to their systems as mixed, with the initial investigative stage primarily inquisitorial and the trial stage primarily accusatorial, because, at the latter, the prosecutor acts as a party. See Damaska, supra at 558-59, 561. The term "inquisitorial" has often been used in a more popular sense to describe a system of coercive interrogation. See Kunert, Some Observations on the Origin and Structure of Evidence Rules Under the Common Law System and the Civil Law System of "Free Proof" in the German 
principle of compulsory prosecution bars discretion in charging serious offenses and permits relatively little in charging minor ones; even reports more credible to American observers maintain that while discretion is frequently exercised, it is effectively regulated by statutory standards. ${ }^{8}$ In Italy, all offenses are said to be prosecuted to the extent the evidence allows, with the entire process under judicial direction. ${ }^{9}$

Code of Criminal Procedure, 16 Buffalo L. Rrv. 122, 122 n.3, 125 (1966). The evolution of German procedure illustrates the nature of the mixed systenus:

Under the modern accusatorial system, introduced after the 1848 revolutions in the German states, the trial judge's function has become entirely separated from the investigatory and the accusatory functions ....

....

The accusatorial principle, with the requirement of the public prosecutor investigating the case and filing a charge sheet before the case could reach the trial court, was introduced throughout. This distinguishes modern German criminal procedure most sharply from the old inquisitorial system where the investigating judge and the trial judge were either identical, or where the trial judge adjudicated the case on the basis of the dossiers of the investigating judge according to the "legal proof" rules, without ever having seen the accused face to face. Furthermore, the principles of publicity, orality, and inmediacy were made basic requirements of the criminal trial; that is, the whole case had to be tried to the judge or panel that decided the case, and nothing but what had been discussed in open court could be made a basis for the verdict and the sentence.

Id. at 148. This separation of the investigatory and trial functious has been sharpened by the recent abolition of the examining magistrate, a change that left the prosecutor as the only official charged with directing pretrial investigations. See pp. 259-60 \& note 49 infra.

8. Professor Hans-Heinrich Jescheck quotes "the so-called legality principle-Legalitätsprinzip," stated in art. 152(II) of the German Code of Criminal Procedure, which provides that the German prosecutor " "is obligated, unless otherwise provided by law, to take action against any activities which may be prosecuted and which are punishable in a court of law, to the extent that sufficient factual particulars may be obtained.' " Jescheck, The Discretionary Pou'ers of the Prosecuting Attorney in IVest Germany, 18 AMr. J. CoMr. L. 508, $509(1970)$. For scrious offenses, the prosecutor is said to have no discretion, except that he must determine whether the facts support a charge of crime. "He may not take the question upon himself whether it might not be in the interest of the state or more expedient for the parties to drop the proceedings completely." Id. at 511. Recent articles have concentrated on the manner in which prosecutorial discretion (under the opportunitätsprinzip) may be cxercised for lesser offenses. See Herrmann, The Rule of Compulsory Prosecution and the Scope of Proseculorial Discretion in Germany, 41 U. ChI. L. Rev. 468, 48I-95 (1974); Langbein, Prosecutorial Discretion, supra note 7 , at $450-61$. According to Jescheck, supra at 513 , the cases in which discretion may be exercised "have been gradually widened by statute over the course of the last decades."

On the German system generally, see The German Code of Criminal Procedure (H. Niebler trans. 1965) [hereinafter cited as GERMAN CoDE]. This translation of the Code is sometimes ott of date; subsequent footnotes will indicate relevant amendments made since its publication. See also J. Langbein, Comparative Criminal Procedure: Germany (1977) (containing illustrative documents and transcript material).

9. Criminal Law Education and Research Center, What Can a Police Officer Do? $21-22$ (1973) [hcreinafter cited as CLE. R ]. Article 112 of the Italian Constitution establishes the principle of obligatory prosecution. A prosecutor who violates the principle is guilty of a crime.

The literature available in English on the Italian system is particularly sparse. There is no English translation of the Italian Code of Criminal Procedure. The CLEAR description is the best available summary. Another is the document prepared in connection with 
In France, the law authorizes broad discretion in deciding to chargeunder the "expediency" (or "opportunity") principle, which provides that " $[\mathrm{t}]$ he prosecuting attorney shall receive complaints and denunciations and decide what to do with them."10 But even there it is said that the charging process is under firm judicial control. ${ }^{11}$ These claims are especially intriguing because none of these countries permits defendants to plead guilty. Even when the charge is not contested, a trial must take place and the court must elicit "objective proof" of guilt. One scholar, contrasting Continental practice with guilty pleas and trials in the United States, says the most summary criminal proceeding in the European systems "is not significantly different from the most demanding." 12

If such worlds are possible-if caseloads can be managed in Western European countries without prosecutorial discretion or with discretion carefully controlled, if full judicial inquiry can be made into every offense formally charged-then perhaps we have conceded too much power to the prosecutor, relied too much on plea bargaining and the guilty plea, and ignored the role that judges may play in supervising the prosecution of crime. Kenneth Culp Davis has already looked to German theory and practice in arguing that a criminal justice system need not embrace discretion as uncritically, or as broadly, as we have done in the United States. ${ }^{13}$ A National Advisory Commission has recommended the abolition of plea bargaining and, in language echoing Continental claims, has asserted that prosecutorial discretion can itself be sub-

the London Agreement regarding the Status of the Forces of the Parties to the North Atlantic Treaty, United States Covitry Representative for Italy, Country Law Study FOR ITALY (1958) [hereinafter cited as CounTRY LAw STUdY]. See id. at 8-9. See generally M. Cappelleti, J. Merryman \& J. Perillo, The Italian Legal System 102-09, 112 (1967).

A new Code of Criminal Procedure is being drafted pursuant to the Law of April 3, 1974, no. 108, Gaz. Uff., April 26, 1974, 2915-19. If enacted, it would make dramatic changes in some parts of the Italian system. These contemplated changes are referred to, where pertinent, in subsequent notes. However, enactment of the Code has already been delayed several times, most recently until May 31, 1978 .

10. The quotation is from The French Cone of Criminal Procedure (G. Kock trans. 1964) art. 40 [hereinafter cited as FRENCH CoDE]. Subsequent footnotes will indicate relevant amendments since publication of the translation.

11. See A. Sheehan, Criminal Procedure in Scothand and France 18, 41.43 (1975); Anton, L'Instruction Criminelle, 9 AM. J. Coxp. L. 441, 445 (1960); Pugh, Administration of Criminal Justice in France: An Introductory Analysis, 23 LA. L. REv. 1, 13 (1962); Vouin, The Role of the Prosecutor in French Criminal Trials, 18 AM. J. Comp. L. 483, 488-92 (1970); Vouin, The Protection of the Accused in French Criminal Procedure, 5 INT'L \& Comp. L.Q. 1, 9 (1956) [hereinafter cited as Protection of the Accused].

12. Damaska, supra note 7, at 551. But compare the different impressions of Rosett, Trial and Discretion in Dutch Criminal Justice, 19 U.C.L.A. L. REv. 353, 364-76 (1972), who also describes a system in which there is no guilty plea and in which the trial follows inquisitorial procedures.

13. K. Davis, Discretionary Justice in Europe and America 60.74 (1976); K. Davis, supra note 5 , at $224-25$. 
stantially reduced, perhaps even eliminated. ${ }^{14}$ Academic and judicial commentators are once again suggesting explicit reliance on inquisitorial models of investigation and trial..$^{15}$

It is difficult, of course, to learn whether, and to what extent, these European systems operate in practice without the discretion available to the American prosecutor and without the summary process of the guilty plea. The difficulties are inherent in cross-cultural studies, but they are compounded by the nature of the literature on Continental criminal procedure that is available in English. This literature consists almost entirely of descriptions of the statutes constituting the European codes of criminal procedure. There is little or no case law and very little field research on how the systems work in practice. Even in conversation, scholars and officials describe their system as the Criminal Code prescribes it rather than as it manifests itself in actual operation. Open discussion about what is done in practice-which may involve the disregard of legal norms or the subordination of one norm to another-is rare. While jurists occasionally point to deviations from the formal rules, they make no attempt to do so systematically or to consider whether the deviations alter the way in which the system as a whole should be viewed. The approach contrasts dramatically with an American literature that is better informed by practice and that recognizes a good deal of dissonance between legal norms and legal operations. ${ }^{16}$

Despite the difficulties, we concluded that it would be useful to probe beyond statements of principle and descriptions of Code provisions. We were particularly interested in learning whether discretion in charging is as limited as the literature suggests, what role the judiciary plays in curtailing or controlling discretion, and how the systems function without a formal guilty plea. Recalling that investigative abuse in the United States is dealt with after the investigation ends, by suppression hearings at trial or-far more often-by a "discount" in the charge, we also wished to pursue suggestions that Continental investigations are

14. National Advisory Commission on Criminal Justice Standards and Goals, Courts 46.49 (1973).

15. Sec, e.g., W. Schaterer, The Susi'ect and Society $70-i 1$, $79-81$ (1967); L. WeinReb, DeNiAL of JUSTICE 11-12, 42-43, $117-46$ (1977); Frankel, The Search for Truth-An Umpireal I'iew, 123 U. PA. L. REv. 1031 (1975); Kamisar, Kauper's "Judicial Examination of the Accused" Forty Years Later-Some Comments on a Remarkable Article, 73 Mich.

L. REv. 15 (1974). See generally A. Goldstein, supra note 6, at 1021-25.

16. We have not reviewed the literature in other languages, but discussion with scholars in the three countries confirms the view that there is little or no empirical description comparable to that available about the American system. There are several German exceptions, which are described at pp. 260, 274, 275 infra. On the nature of the American literature, see G. Mueller, Crime, Law and the Scholars 95-108 (1969); A. Goldstein, supra note 6 , at 1009-15. 
directed not by prosecutors or police, but by judges, whose on-thespot supervision provides a better guarantee against investigative abuse than the exclusionary rules applied in the United States. Overall, we had two purposes: we wanted to provide a picture of Code provisions in practice so that the current inclination to "borrow" foreign institutions and concepts would have a more accurate basis; and we wished to lay a foundation for further inquiry-conceptual and empirical-to determine whether there are processes underlying both European and American criminal justice systems that make them more congruent in operation than in theory. What follows is a report on these issues, based on interviews with judges, prosecutors, defense attorneys, and professors in France, Italy, and West Germany, augmented by some observation and a review of the available literature. ${ }^{17}$

\section{Investigation and Charge: Developing the Dossier}

The key to most systems of Continental criminal procedure is to be found in several connected principles. The Penal Code is the foundation of legal authority: Judges and prosecutors have no "inherent" power to take positions that modify or nullify the Code's requirements. And the state has an affirmative obligation to develop in full the facts of every case. ${ }^{18}$

17. The Italian interviews were conducted by Goldstein in Rome, Perugia, and Florence in October 1975. The German and French interviews were conducted by Marcus in Augsburg, Munich, Freiburg, and Paris in Norember 1975. In Italy, we interviewed four public prosecutors, two pretori, three examining judges, three trial judges, one judge of the Supreme Court of Cassation, three defense counsel, and five professors of criminal procedure. In Germany, we intervicwed five public prosecutors, four defense counsel, two magistrates, six trial judges, and four professors of criminal procedure. In France, we interviewed three public prosecutors, two defense connsel, two juges d'instruction, and two trial judges. W'e also observed several trials and requests for warrants in each of the countries. Many of the persons interviewed had served in more than one role, e.g., trial judges had been examining magistrates and professors had been defense counsel.

Before conducting the interviews, we prepared interview outlines that framed the major factual questions emerging from our reading of the relevant statutes and literature. At the end of each interview, we prepared summaries and subsequently incorporated them into memoranda on each of the systems. We noted a common tendency to respond to our questions in terms of formal legal principles. As a result, we regularly turned the discussion to the way in which cases were handled in practice. By asking the same questions of persons serving in different capacities in each system and in cities of varying sizes, we were able to ascertain the nature of agreement and disagrecment on critical questions. In France, however, our interviews were restricted to Paris, because there is more available in English on French procedure and practice. Though the interviews did not provide us with "hard data" on which to base our conclusions, we succeeded in developing an appreciation of how the systems operate and of the relation between formal doctrine and actual behavior, which should provide a basis for more detailed empirical research.

18. On "inherent powers," see Damaska, Structures of Authority and Comparative Criminal Procedure, 84 YaLe L.J. 480, 498, 505 (1975). On the relation between hierarchical models, characteristic of the Continent, and hostility to official discretion, see id. at 485 , 487. See generally notes 7 -10 supra. 
The primacy of the Code is said to be enforced in Germany and Italy by the "principle of legality," which makes prosecution compulsory and discretion in charging impermissible unless specifically authorized by statute. Even where some prosecutorial discretion is accepted, as in France, it is construed narrowly. The Code's provisions are to be applied rigorously by prosecutors and police, both of whom are organized nationally and hierarchically and are subject, in theory, to greater control by superiors than under American practice. The principal assumption, however, is that the judiciary must play a central role in assuring that the Code is properly applied: only judges are sufficiently impartial to be entirely trusted with its enforcement.

Inquisitorial theory recognizes that the key to overall judicial supervision is control of the investigation of crime. Unless the judge plays a role in determining how investigations should be conducted, or what charges should be filed, his supervision will be limited to the cases that survive for trial as a result of decisions by others. In its relatively "pure" form, which still dominates Italian procedure generally and French procedure in cases of serious crime, the system maintains judicial control of the pretrial investigation through a number of requirements. The police must report all offenses to the prosecutor, who must then open a file-a dossier-and refer the matter to a judge for "examination." Police are placed at the disposal of the examining judge, who must decide whether there is enough evidence to justify prosecution. To that end, he is given the power to order arrests and searches, take testimony under oath, and interrogate the accused-all the while recording the results of the investigation in the dossier. ${ }^{19}$ The critical investigative and charging decisions are to be made by the judge, or authorized and reviewed by him. And nonjudicial officials have no authority to terminate a case reaching a certain level of evidentiary sufficiency, or even to determine the seriousness or number of the charges on which a defendant is ultimately tried..$^{20}$

This examining judge or magistrate looms large in the literature of comparative criminal procedure and serves as a model for those who would give the American judiciary a direct role in supervising the investigation and charging processes. $\mathrm{He}$ has been described as combining

19. On the dossier and what it must contain, sce A. SHEEHAN, supra note 11 , at $48-49$ (France); Anton, supra note 11, at 452-55 (same); J. L.tNGbein, supra note 8, at 8, 12, 67 (Germany); Country LAw Study, supra note 9, at 19-21, 24-25 (Italy).

20. A. Sheeh.s, supra note 11, at 41-43; Langbein, Prosecutorial Discretion, supra note 7 , at $446-47$. In Italy, judicial approval is required for dismissals of virtually all cases-major and minor-with the exception of a limited category of private prosecutions known as querela. See CLE.AR, supra note 9, at 28-29; note 72 infra. 
" 'the absolute integrity and impartiality of the judicial office with the power of the prosecution and the investigative skill and expertise of the police and the powerful reach of the grand jury'."21 The practice, however, is in striking contrast to the myth. Either the examining magistrate has been eliminated entirely, as recently occurred in Germany, or he conducts the pretrial investigation in a relatively small number of cases, as in France and Italy. The police and prosecutor prepare the dossier in Germany, and judicial supervision is preserved only through the aggressive inquisitorial role assigned to the trial judge, who is expected to bring out all the "objective facts." 22 In France and Italy, the magistrate's role in the small number of pretrial investigations he conducts is a limited one. In both countries, it is the prosecutor who decides whether there need be a judicial examination, and he usually decides that there is no need; he keeps the case and conducts the examination himself.

Whether it is the magistrate or prosecutor who conducts the formal investigation, most investigative work has been completed by the police before the other officials enter the picture-because the police learn about the crime first, are better trained than prosecutors or judges to use the technology of factfinding, and often wish to avoid the formal procedures applicable to the "examination." ${ }^{23}$ Prosecutors and examin-

21. Mueller \& Le Poole, The United States Commissioner Compared with the European Investigating Magistrate, 10 CRIM. L.Q. 159, 172 (1968) (quoting Mueller, Lessons of Comparative Criminal Procedure (unpublished lecture delivered at American University on Apr. 23, 1965)). See generally Keedy, The Preliminary Investigation of Crime in France, 88 U. PA. L. REv. (pts. 1-3) 385, 693, 915 (1940); Larguier, The Preliminary Investigation by the French Juge D'Instruction, 19 N. IR. L.Q. 32 (1968); Ploscowe, The Investigating Magistrate (Juge D'Instruction) in European Criminal Procedure, 33 Mich. L. Rev. 1010 (1935); see also Wise, Book Review, 21 AM. J. Comp. I. 806 (1973) (reviewing P. Chambon, Le Juge D'Instruction). In France, the pretrial investigation or examination by a judge is known as instruction; in Italy, as istruzione.

22. See Schmidt, Introduction, in German CODE, supra note 8, at 16-17. The translation of the German Code predates the virtual elimination of the examining magistrate in 1975 , see p. 259 \& note 49 infra, and, therefore, includes sections relevant to the then-existing authority of the examining magistrate to conduct an investigation. Judges, through the office of the magistrate (Ermittlungsrichter), retain authority to issue arrest and search warrants. See p. 259 \& note 49 infra.

23. In France and Italy, many of the procedural rights of the accused accrue only when the judicial examination begins. The defense attorney, for example, may attend when an accused is interrogated by the examining magistrate but not when he is questioned by the police. Similarly, if the examining magistrate arranges for the accused to be confronted by witnesses, counsel may attend. See French CODE, supra note 10, arts. 114-116, 118; Vouin, Police Interrogation Privileges and Limitations: France, 52 J. CRIM. L.C. \& P.S. 57 (1961). An amendment to the French Code, effective January 1976, provides that when a suspect charged with a flagrant misdemeanor punishable by imprisonment is brought to the prosecutor for interrogation, the prosecutor must inform him of his right to be assisted by counsel, though this right may be waived. Law No. 75.701 of August 6, 1975, art. 7. As to Italy, see CLEAR, supra note 9, at 196-97. In Germany, an accused person may consult with his attorney before interrogation by the prosecutor. German Code, supra note 8, \$\$ 136(I), 163a(III). The police need not offer the accused 
ing judges generally do little more than confirm what the police have already done. Even when new lines of inquiry are opened, the necessary investigation is ordinarily delegated to the police under very broad authorizations-despite statutes requiring that such delegation be narrow and specific..24

The relative lack of judicial control and the independence of police and prosecutors are reconciled with inquisitorial theory by resort to fictions. The public prosecutors in France and Italy are treated as part of the judiciary, and their investigations are considered to be conducted in their "judicial" capacity. Similarly, the abolition of the examining magistrate in Germany has been explained not as an attempt to replace a judicious magistrate with a partial prosecutor, but rather as based on the assumption that the prosecutor can conduct as impartial-as "judicial"-an investigation as a member of the judiciary. In France and Italy, the police who investigate criminal complaints and prepare them for prosecution are called "judicial police," although they are members of the regular police forces and are not employed by the judicial department. In the case of both prosecutor and police, it is the capacity in which they act, rather than their institutional position, that is held to define their character. ${ }^{25}$

an opportunity to consult with counsel until their second examination. At the first, they need tell him only the offense with which he is charged. Id. $\$ 163 a(I V)$. It should be noted that persons accused of crime are less likely to be arrested and detained in these countries than in the United States. Something like our summons ordinarily begins most procecdings.

24. In France, the examining magistrate may issue a "rogatory commission" that authorizes the police to act for him, though such commissions may not be used to authorize interrogation of an accused. FRENCH CODE, supra note 10, arts. 151-155. A "typical" rogatory commission reads: "Proceed to hear all necessary witnesses under oath; undertake in accordance with the law all confrontations, visits, searches, seizure of evidence and all necessary steps to identify the person or persons . . . responsible for the offense..." A. SheEhan, supra note 11, at 57. "[I]t frequently happens that an examining magistrate, seised of a crime committed the day before, delegates the examination-and hears no more of the crime for several months!" Vouin, Protection of the Accused, supra note 11 , at 14. See also Anton, supra note 11, at 446-47. For similar observations regarding Italy, see CLEAR, supra note 9, at 27-39.

Proposals have recently been made in connection with the preparation of a new Code of Criminal Procedure, see note 9 supra, that would make the Italian police turn more often to the examining magistrate for authority to conduct their investigations, under narrower limits than now prevail. The proposals would also assign police officers to the prosecutor and the court to assist them in carrying out their investigative duties. Some observers regard such assignments as limited devices, to be used only in extraordinary situations; others view them as opening the way to a new era of detailed judicial supervision of police investigation in complex cases.

25. The French prosecutor is often referred to in the literature as the parquet, the judge whose place is on the floor rather than on the bench. While most prosecutors, in conversation, do not consider themselves to be judges, Sheehan observes that "[ $[$ ] judiciary and the public prosecutor have equal privileges, status and salary. Interchange between the two branches is simple and not uncommon. . . The prosecutor does not regard himself (nor is he so regarded by the judge) as being inferior to the judge ....." 
Whatever the effect of treating prosecutor and police as in some measure "judicial," Continental processes of investigation cannot be fully understood unless we penetrate the myth that judges conduct or supervise police investigation. The plain fact is that examining magistrates are no more likely than comparable American officials to leave their offices, conduct prompt interrogations of witnesses or of accused persons, or engage in searches or surveillance. For such tasks, they rely almost entirely upon the police. A "judicial examination" generally means only that a judge must formally authorize certain aspects of the criminal investigation in advance-for example, the length of the detention, the interrogation, the search, the medical tests. But as we shall see, this authorization often occurs after the fact and confirms the validity of "informal" measures already taken by the police. The judge's investigative role, therefore, is essentially reactive and interstitial. Much the same situation exists when "legal" supervision of the investigation is assigned to the prosecutor or shared with him. Even though initiative in investigation is more consistent with the prosecutor's role than with the judge's (at least when viewed from an American perspective), prosecutors, too, have proven to be relatively passive and reactive and have left it largely to the police to develop the facts to be entered in the dossier.

\section{A. France}

In France, an examination by the examining magistrate-the juge d'instruction-is mandatory only for crimes (punishable by imprisonment for five or more years) triable in the Courts of Assize. These represent a small fraction of criminal cases. For délits, which are punishable by imprisonment for two months to five years and are triable in the Correctional Court, the prosecutor has discretion to order a judicial examination, ${ }^{26}$ but he rarely does so. In 1971 , only

A. ShefhaN, supra note 11 , at 11 . In Italy, the prosecutor is freely characterized as a judge. CLEAR, supra note 9 , at 26 . He is a member of the judiciary, recruited in the same way as judges, and enjoys "all the guarantees (e.g., independence, irremovability, and salary) assured the judges." Vigoriti, The Role of the "Ministere Public" in Civil Proceedings: Italy, in Italian National Reports to Ninth INTERnational Congress of Comparative Law 270 (1974). In Germany, it is said that "[t]he prosecution is . . . not a party opposing the defendant" and that it must "serve truth and justice." Schmidt, supra note 22, at 11; see Jescheck, supra note 8, at 510. In France, police detectives are formally classified as members of the "judicial police." Frencr CoDE, supra note 10, arts. 12-30. In Italy, "[t]here is no distinct corps of judicial police"; they are regarded as "judicial police" when they conduct criminal investigations in aid of prosecution. CLEAR, supra note 9 , at 30 .

26. French CODE, supra note 10, art. 79. The Tribunal Correctionnel is referred to here as the Correctional Court. Contraventions or violations-offenses punishable by less than two months incarceration-are triable in the Tribunal de Police and do not receive a judicial examination. See generally A. SheEhAN, supra note 11, at 76-81. 
$14.5 \%$ of all crimes and délits were sent to a juge d'instruction. ${ }^{27}$ This figure, however, is only partially explained by the reluctance of the prosecutor to order judicial examination of délits. Even in cases of crimes, there may be no judicial examination; the prosecutor may ignore aggravating circumstances and treat an offense as a "lesser included" délit. Through this process, known as "correctionalization," a crime like theft committed at night (or in a home or with a weapon) may be converted into the délit of simple theft. ${ }^{28}$ The French prosecutor's reasons for "correctionalizing" a crime are as varied as those customarily offered by the American prosecutor when he decides to reduce the number or degree of offenses charged. ${ }^{29}$ Although "correctionalization" is commonly characterized as extralegal-falling outside the bounds of the prosecutorial discretion authorized by the "expediency" principle-it is an everyday occurrence and is accepted by officials at every level. ${ }^{30}$ And whatever the motive for "correctionalization" may be, its effect is to bypass the judicial examination. It is not that "correctionalized" cases may not on occasion include a judicial examination but rather that the prosecutor usually decides that there is no need for participation by the juge and sends the case directly to trial.

There are, however, practical limits on the prosecutor's discretion to "correctionalize" a case. If a defendant wishes to risk a higher sentence in the Court of Assize, because the acquittal rate there is higher or because there are more pretrial screens from which he may emerge uncharged, he may keep the Correctional Court (Tribunal Correction$n e l)$ from taking the case. If the victim seeks a greater penalty than

27. An official of the Ministry of Justice in Paris, quoting from the national statistics, said that in $1971,69,000$ out of a total of 470,000 cases heard in the Correctional Court had received a prior judicial examination. Interview with M. Jacques Verin, Director of Research, French Ministry of Justice. In Paris, in 1970, of 66,324 prosecutions for crimes and délits, 11,939 were investigated by an examining magistrate. The total number of cases prosecuted as crimes in the cour d'assises in Paris in 1971 was 78. A. ShenhaN, supra note 11 , at 47.48 . Comparable figures have been cited for the 1920s. Ploscowe, supra note 21 , at 1012 .

28. For an early description of "correctionalization," see Ploscowe, Development of Inquisilorial and Accusalorial Elements in French Procedure, 23 J. CRIM. L. \& CrimINoLoGY 372, 386-87 (1932). More recent accounts are A. SHEEHAN, supra note 11, at 6; Freed, Aspects of French Criminal Procedure, 17 LA. L. REv. 730, 739 (1957).

29. A French judge, explaining "corrcctionalization" to us as a means of ameliorating the harshness of the French Penal Code, predicted that the device would survive the expected reforms of the Code's sentencing provisions. When asked whether "correctionalization" should be explicitly provided for in the Code of Criminal Procedure, he emphatically resisted the suggestion. His reason, ironically, was that correctionalization, albeit a necessary part of the system, was completely contrary to the principles of French law.

30. Prosecutors sometimes "correctionalize" a crime because they believe that the jury would acquit rather than subject the accused to the higher sentence. A. SheEHAN, supra note 11 , at 6 . 
the Correctional Court can impose, he may press his orvn criminal complaint, thereby forcing examination before a juge..$^{31}$ And the Correctional Court may itself decide that it would be inappropriate to try the case as a delit because of the aggravating circumstances that the prosecutor has chosen to ignore-provided, of course, that the police and prosecutor have not omitted such circumstances from the dossier.

But the most important limits on the prosecutor's discretion are those imposed by the nature of a particular case. Some crimes are not "correctionalized" because they are complicated or serious or controversial. In some instances, judicial examination is regarded as appropriate because the case has been widely publicized or because political considerations are involved. In others, it is genuinely necessary because police and prosecutors have only limited powers to arrest, search, summon witnesses, and interrogate the accused. When more thorough investigation is needed, the prosecutor may not simply seek a subpoena or a warrant from the juge; the entire investigation must be turned over to him. For example, the police may hold a suspect on their own authority for twenty-four hours; and in some cases the prosecutor may authorize detention for an additional twenty-four hours. ${ }^{32}$ But if further detention is needed in order to continue the investigation, as is often the case, the matter must be turned over to the juge. The same is true if a search is necessary and the individual whose place or person is to be searched refuses his consent, or if a witness

31. In France, the victim of an offense can initiate a prosecution by filing a complaint with the juge, or he may join in a prosecution already instituted by the prosecutor. If the victim, as partie civile, files his own damage action with the juge, the prosecutor may not rely on the discretion otherwise available to him under the "expediency" principle and decide not to charge a crime or not to pass the matter on to a juge. He may refuse to authorize judicial investigation only on evidentiary grounds. FreNCH CODE, supra note 10 , art. 86 . But if he does so, the result is not an investigation by the prosecutor but a termination of the case. Upon conviction, the criminal court can award the victim, as partie civile, damages as compensation for his injuries. The partie civile may also appeal certain decisions made by the examining magistrate, prosecutor, or trial court. FRENCH CODE, supra note 10 , art. 575 . On the partie civile procedure, see gencrally A. Sheehan, supra note 11, at 20-23; Larguier, The Civil Action for Damages in French Criminal Procedure, 39 TuL. L. Rev. 687 (1965). On the role of the victim generally, and the relation of his damage action to the criminal case in Germany and Italy, sce notes 72 \& 80 infra.

32. The police may arrest and detain a suspect for 24 hours incident to their authority to conduct investigations of flagrant offenses. This is known as the garde $a$ vue. Frencil CODE, supra note 10 , arts. 63,77 . An offense is regarded as "flagrant" if it "is in the process of being committed or . . . has just been committed" or if "in the period immediately following the act, the suspected person is pursued by clamor, or is found in possession of objects, or presents traces or indications, Icading to the belief that he has participated in the felony or misdemeanor." Id. art. 53. The detention may be cxtended by the prosecutor beyond the initial 24 hours only when there is stubstantial incriminating evidence "indices graves et concordants," sometimes translated as "grave and concordant indications"). A. SheEHAN, supra note 11 , at 37 . See note 34 infra. 
with crucial testimony declines the invitation of police or prosecutor to give his information voluntarily. ${ }^{33}$

The prosecutor's decision to "correctionalize" a case is rarely upset, because the accused, the victim, and the court all have an interest in treating the case as a délit. For the accused, it means a lesser penalty. For the victim, it provides a surer result and a quicker award of the damages that may ensue upon conviction of the accused. For the court, it serves the institutional needs of a system too burdened by its caseload to try every case to its full extent, while also satisfying sentencing considerations. The sentences available in the Correctional Court are widely regarded as more appropriate to most cases than the severe sanctions fixed by French law for crimes.

Similarly, the need for the prosecutor to turn the investigation over to the examining magistrate rarely arises. Most accused persons cooperate with the police by confessing their crimes and by providing leads to witnesses and evidence against them. Most witnesses volunteer their testimony, not knowing that they need not cooperate. Consent to search without a warrant is routinely given. In any event, the police have broad authority to search incident to arrest. And in cases of "flagrant" offenses-the analogue of the American cases in which the investigation is conducted in "hot pursuit"-they need no prior judicial authorization to search, to seize, or to summon witnesses. Moreover, in such cases they may arrest and detain the accused for twentyfour hours-the period of the garde $\dot{a}$ vue-which usually provides sufficient time for inquiries to be made. The police regularly characterize ordinary offenses as flagrant ones in order to avoid the restrictions that would otherwise apply. Courts acquiesce in the practice, either by ignoring reality or by defining "flagrant" so broadly that the exceptional case becomes the rule. ${ }^{34}$

33. See generally French Code, supra note 10, arts. 79-190 (describing authority of examining magistrate; especially arts. 81, 92-97, 101, 114-121, 122-155).

34. See Vouin, Police Delention and Arrest Privileges Under Foreign Law: France, 51 J. Crim. L.C. \& 1'.S. 419, 420 (1960). See also FreNCH CoDE, supra note 10, art. 54. The garde a vue procedure may be used for flagrant crimes and flagrant délits. Id. art. 63. In addition, the head of a houschold in which an offense has been committed may request the prosecutor or judicial police to treat the offense as flagrant. Id. art. 53. Sheehan suggests that only an offense that was not reported "as soon as it came to light" would not be treated as flagrant. 1. SureudN, supra note 11, at 40. See also note 32 supra; Norton, Trulh and Individual Rights: A Comparison of United States and French PreTrial Procedures, 2 Ax. CRIM. L.(). 159, $161-63$ (1961).

Even if inquiries can be completed within the twenty-four or forty-eight hour detention period allowed police and prosecutor for the garde ad vue, there may not be sufficient time to get the case to trial. Rather than make the prosecutor choose between releasing a defendant whose case is ready but not yet called for trial and requiring-in order to continuc his detention-that the examining magistrate duplicate an investigation the 
These observations make clear that prior judicial authorization of arrests, interrogations, searches, and seizures is rare. Given the similar American experience with arrest and search warrants, this is hardly surprising. What is surprising, in light of assertions that Continental judges supervise investigations, is that even review after the fact is likely to be superficial and ineffective. Under the Code, such review may occur when an examining magistrate is asked to intervene in the investigation and extend detention beyond the limited period authorized for the garde $\dot{a}$ vue; he may then have occasion to review the earlier arrest. Similarly, if the magistrate opens an investigation, he may be able to review searches and seizures conducted earlier by the police. $^{35}$ In these circumstances, however, the accused does not obtain from the examining magistrate a review of the original police decision to detain him or to search his home or belongings. The magistrate does not regard it as his responsibility to look back at the legality of those decisions, but only to determine whether there is now a basis for the detention to continue and for the judicial examination to proceed.

The trial judge is even less likely than the juge to inquire into allegations that the police violated provisions of the Code in the course of developing the dossier. The legality of the original arrest is not regarded as relevant to the trial. Police investigations are generally treated either as "informal" or as proper because they are necessary for the preservation of public order. Rarely do trial courts question searches as resulting from unduly broad interpretations of what is a "flagrant" offense or of what constitutes consent. The French Code refers to "nullifying" illegal investigatory acts by striking them from the dossier, but these provisions are aimed primarily at the magistrate's examination, and not at the investigative activities of the police. Unlawful arrests, searches, and seizures by the police are not nullified, and their product-what we call "the fruit of the poisonous tree"-is regularly used in the pretrial examination and the trial. Only if the police ask a suspect incriminating questions without informing him of his right to refuse to answer and to be taken before the juge is there some possibility of nullification, and even that irregularity is often

prosecutor considers already complete, the Code permits a flagrant misdemeanor to be tried on an expedited basis, within the period of detention that the police and prosecutor can themselves authorize. Apparently, however, dockets are so crowded that another solution has become necessary. Verin and Strasburg report that judges, before whom defendants charged with flagrant misdemeanors appear, often extend detention beyond the 48 hour period, "usually for periods of a week at a time." Verin \& Strasburg, International Cooperation in Action Research: A French-American Example (to be published in Int'l ansals of Criminoloriy).

35. See generally FreNCII CODE, supra note 10, arts. 114-136. 
ignored. ${ }^{36}$ In general, the defendant who complains of an unlawful arrest or search is left to bring a civil or criminal action against the police, which may be costly and which will almost certainly be unsuccessful.

The power of the French police to conduct an investigation is so broad that, as one official noted, they may have completed "the whole job of the investigating magistrate" before even notifying the prosecutor of the commission of the offense. As a result, the overwhelming proportion of délits is likely to proceed to trial with a dossier that is little more than a police report. And while the most important and complex crimes are investigated carefully by a juge, large numbers of crimes are tried on the basis of dossiers in which his role has been intermittent and perfunctory. Moreover, the procedural regularity of the dossier in both settings-that of délit and that of crime-is treated as virtually conclusive. Behind the veil of the formal requirements of the Code, the French dossier, the manner in which it is compiled, and even its contents may not be as different from an American prosecutor's

36. The issue of nullification is raised during the pretrial hearing in the Chamber of Accusation, see note 58 infra, if the offense is a crime, and at trial if it is a delit. French Conc, supra note 10, arts. 171, 174. See Vouin, French Criminal Procedure, in THE Accused 209, 213 (J. Coutts ed. 1966). Reports in the literature concerning nullification are often conflicting. For instance, it has been asserted that a conviction could not be based on "illegal proof" and that illegally seized evidence and illegal confessions may not be used in judicial proceedings. But it has also been noted that an explicit statement by the judge that his decision did not rely on an illegal search may save a conviction. Vouin, The Exclusionary Rule: France, 52 J. Crim. L.C. \& P.S. 275, 275 (1961). See Hrones, Interrogalion Abuses by the Police in France-A Comparative Solution, 12 CR1M. L.Q. 68, 75-77 (1969). And Shechan says the nullified acts may in any case be redone. A. SHeEHAN, supra note II, at 64 . For other observations that the exclusionary rule is generally ineffective in presenting the use of illegally obtained evidence, see Damaska, supra note 7, at 522; Norton, suprn note 34 , at 162 . As to interrogations, the Code provides that the police may not under a rogatory commission "hear as witnesses persons against whom there exist grase and concordant indications of guilt," if the questioning is conducted "with the intention to cut off the rights of the defense." FRENCH CODE, supra note 10, art. 105. . Iccording to one commentator, the privilege against self-incrimination "does not apply to interrogations conducted by the police on their own behalf." And the protection offered by Article 105 is "meager" because the courts have strained to find that interrogations authorized by a rogatory commission are not conducted for improper purposes. Pieck, The Accused's Privilege against Self-Incrimination in the Civil Law', 11 Ax. J. Coxrr. L. 585, 591, 593-94 (1962). The same approach may well be taken toward all claims of illegal investigatory acts under a recent amendment that limits nullification to cases in which there is a showing that "the irregularity has the effect of infringing the interests of parties concerned," i.e., of causing actual prejudice. Law No. $75-701$ of August 6, 1975, art. 19, published in 107 Jocrsil Officiel DE LA Republique Frincaise 8035,8037 (Aug. 7,1975 ).

Criminal actions for unlawful arrests, searches, etc., usually fail because the aggrieved defendant is unable to prove the scienter the law requires. According to those interviewed, civil suits for damages are possible, but the chances of success are bleak. Compensation is available, however, to an accused who is acquitted after a period of pretrial detentionnot as a remedy for tulawful conduct, but as recognition of the injustice done by incarcerating an iunocent person. 
file as is commonly supposed. It is not often the product of the judicially conducted or supervised investigation contemplated by inquisitorial theory.

\section{B. Italy}

In Italy, the "inquisitorial" model is more solidly entrenched in the law than in France. Not only is there an examining magistrate for serious offenses, but when the prosecutor prepares the dossier for trial he must comply with the same rules of examination as the magistrate, and he has the same powers to arrest, search, and interrogate. ${ }^{37}$ Minor offenses are tried by the pretore, who is like an inquisitorial judge of old-combining prosecutorial and adjudicative functions..$^{3 \mathrm{~s}}$

Nevertheless, the Italian experience replicates the French. There are remarkably few examinations conducted by a judge before trial. Most cases before the pretore proceed to trial entirely on the police report. ${ }^{30}$ Even in the investigation of more serious offenses, the prosecutor is authorized to decide whether he should retain the case for examination or pass it on to an examining judge. Though statutes purport to confine the prosecutor's examining role to cases in which the accused is

37. The prosecutor's investigation is often referred to as an "informal" examination because, until recently, it allowed fewer rights to the defendant and his counsel than were available in the "formal" examination conducted by an examining magistrate. Today, however, both prosecutor and magistrate operate under the same rules and with the same powers. Sce cases and commentary in M. Cappelletti, V. Vigoriti, N. Trocker, D. Wilson \& V. Grementiert, Comparative Cases and Materials on Constitutional Guarantees Governing Judicial Proceedings I-28 to I-35, I-39 to I-40 (1972) (referring to cases of Venieri, June 26, 1965, No. 52, and Amaducci et al., June 5, 1968, No. 86; and Law of Dec. 5, 1969, No. 932, which rephrased Article 225 to state that "during the preliminary investigations the rules of the istruzione formale must be observed.") Id. at I-39. See also Merryman \& Vigoriti, When Courts Collide: Constitution and Cassation in Italy, 15 AM. J. Comp. L. 665 (1967). If the prosecutor wishes to detain an accused person, he must obtain the approval of an examining magistrate. The prosecutor may appeal to an appellate panel if his request is denied.

38. At trials before the pretore, the prosecution is conducted by someone other than the pretore-"usually a lawyer, mayor, or town official, who has been seconded for the purpose." CLEAR, supra note 9, at 26. The prosecutor has no concurrent jurisdiction to conduct the examining phase. He may, however, claim that the offense is serious enough to fall outside the pretore's jurisdiction. Where such jurisdictional conflicts are not settled informally, they may have to be resolved by the Supreme Court of Cassation. The prosecutor may, of course, decide not to proceed on the higher charge and leave the case to be prosecuted, if at all, by the pretore. This may produce a functional analogue of the French practice of "correctionalization." See p. 251 supra \& p. 269 infra.

39. This fact is sometimes used to rebut the complaint that the pretore cannot be an impartial judge at the trial of a case for which he has conducted the examination. It is said that in most cases he does not really investigate, but merely acts in response to materials presented to him by the police. In any event, the argument that the combination of prosecutorial and adjudicative functions deprives him of his impartiality has been rejected by the Italian Constitutional Court. Under a new Criminal Procedure Code now under consideration, see note 9 supra, the pretore's examining responsibilities will be abolished and taken over by the prosecutor's office. 
caught in the act or confesses, or in which "the research of the evidence is expected to be simple and rapid" and "there is no need for complex inquiries and difficult verifications," 40 these categories are broad enough to give prosecutor and examining judge substantially concurrent investigative power. It was estimated that the prosecutor "examines" in seventy to ninety percent of cases in which an examination occurs-"in difficult and complex cases as well as in simple ones" ${ }^{11}$-and retains control of both the facts in the dossier and the charges presented for trial.

There are other constraints on the prosecutor's ability to keep cases from examination by the magistrate, but they are limited. The accused may ask that his case be sent to an examining magistrate and may petition the magistrate for review if the prosecutor is unwilling to give way. But such actions are rare, as is review by the prosecutor's superiors. Moreover, the prosecutor has forty days in which he can conduct his investigation free of judicial intervention. It is only when the accused is detained for a longer period that the file must be sent to an examining judge to decide whether further investigation and detention are justified. But if the accused is not in custody, the prosecutor may allow the investigation to grow stale and eventually send the file "to the archives" after obtaining token and belated judicial approval of the decision to terminate the investigation. ${ }^{42}$

In Italy, as in France, then, judicial control of pretrial investigation is more nominal than real. Even when formal judicial procedures are followed, the police play the active role. Details of investigation are left to them by the examining judge, the prosecutor, and the pretore. ${ }^{43}$

40. Country Law Study, supra note 9, at 19.

41. CLEAR, supra note 9, at 28. Under the proposed Code of Criminal Procedure, see note 9 supra, the prosecutor would be required to complete his examination within ninety-six hours of arrest if the accused is detained and within thirty days if he is not. This restriction on his authority may effectively limit his examination to simple cases and force him to send complicated cases on to the examining magistrate.

42. Article 74 of the Italian Code of Criminal Procedure authorizes the prosecutor to archiviare the notitiae criminis when there is plainly no basis for criminal prosecution. This provision was regarded as consistent with the principle of obligatory prosecution until 1944, when it was concluded that a prosecutor might keep from the courts some cases in which the facts might warrant prosecution. The Law of September 14, 1944, no. 288, now supplements Article 74 by providing that the prosecutor may no longer decide for himself on archiviazione. Instead, he must now ask the examining magistrate for formal approval of his decision not to proceed. A magistrate who denies such a request will retain the case and conduct the examination.

43. CLEAR, supra note 9, at 29 ("Although regarded as agents of the prosecutor, the judicial police incvitably tend to operate with a certain autonomy, and this is especially so in those cases where immediate action is called for.") As to when the judicial police may act on their own initiative and when judicial authorization is required, see $i d$. at 33-37. As to their power to "inspect" persons and places, see id. at 110-20.

[A]rticle 13 of the Constitution allows the police to restrict personal liberty without 
Though the police may not issue arrest or search warrants, such "judicial" powers are rarely required. Arrests may be made without warrant for certain flagrant offenses and for nonflagrant offenses if there is a "justifiable cause for belief" that there is danger of flight or if there is "strong reason" to believe that the suspect committed the offense. ${ }^{44}$ Consent to search is usually given, and, in any event, there is broad power to search without a warrant incident to arrest. The occasional warrants sought in advance are routinely issued after a perfunctory review and need not be supported by sworn statements. ${ }^{45}$

The power of the police is enhanced by the fact that their actions are not subject to any real review by the prosecutor, examining judge, or trial court, except in the rare instance in which these officials bring criminal charges against the police. In the usual case, no inquiry is made into the legality of the procedures used by the police or the substantive basis for the search. Similarly, when the prosecutor or judge determines whether the offender should be released or detained during the examination, ${ }^{46}$ he does not use the occasion to review the police action. He does not question whether a statutory basis for the arrest actually existed or whether the police acted illegally. He does not nullify an arrest even if the grounds that justify it are a product of illegal conduct-as through a search incident to an unquestionably invalid arrest. If the trial court should conclude that the examination was based to a significant extent on an invalid procedure, such as an unlawful interrogation, it may, in theory, return the file to the examining magistrate or prosecutor with a request that the defective procedure be redone. But if there is enough evidence to proceed without the contested material, the "null" procedures are usually ignored. ${ }^{47}$

prior judicial approval "in cases of necessity and urgency. ..." Article 14 ... carves out a roughly similar exception to the guaranteed inviolability of a dwelling-place. In these exceptional cases, the police are permitted to take "provisional measures" on their own initiative. ... [Such measures] may be adopted . . . for reasons of "public safety and security." ...

The notion of "public safety" is sufficiently elastic to permit a good deal of surveillance by the police over the activities of private citizens, and there is no objection to the use of evidence thus uncovered in criminal proceedings.

Id. at 118-19. As to searches, see id. at 149-54; as to interrogation, see id. at 129-36.

44. Country Law Study, supra note 9, at 13.

45. CLEAR, supra note 9, at 110-20. A search warrant may be obtained from the prosecutor, examining judge, or pretore, but the police usually approach the prosecutor. This is true also of requests for wiretapping orders. $I d$. at 64 .

46. Within forty-eight hours of an arrest for an ordinary offense and twenty-four hours of an arrest for a flagrant offense, the prosecutor must interrogate the person detained and either validate the arrest or order the release of the accused. Arrest is mandatory for flagrant offenses punishable by more than three years imprisonment and discretionary for lesser offenses. CounTRY LAW Study, supra note 9, at 12-14. The review of arrests for minor offenses is made by the pretore rather than the prosecutor.

47. See Scaparone, Police Interrogation in Italy, 1974 CrIM. L. REv. 581, 585-86; 
In short, procedural irregularities in the course of investigation are likely to have little effect when the case goes to trial. The emphasis is on the substantive basis for the charge. At no point, before trial or after, do courts systematically examine dossiers to assure the regularity of police investigations. The dossier, which plays so central a role at trials above the pretore level, proves to be, as in France, little more than a police file formally validated after the fact by a prosecutor or an examining judge.

\section{Germany}

In Germany, there are two classes of crimes: Verbrechen, which are punishable by imprisonment for one year or more, and Vergehen, which are ordinarily subject to imprisonment for less than one year. ${ }^{48}$ The same investigative procedure has been applicable to both since 1975 , when examination by an investigating judge was abolished because it was thought to duplicate unnecessarily the work already done by the public prosecutor. Responsibility for pretrial investigation is now vested entirely in the prosecutor, who need call on a magistrate only if an arrest or search warrant is required. Indeed, the police may obtain such warrants from the magistrate only through the prosecutor. ${ }^{49}$

Scaparone \& Secci, Right to Silence in Italian Criminal Procedure, in Italian Nationat Reports to Ninth International Congress of Comparative Law 684 (1974). But cf. CLEAR, supra note 9, at 218 (assuming that "it follows logically" from a recent decision of Italian Constitutional Court that "any act by which the police obtain evidence illicitly or in breach of the pertinent procedural rules will be invalid and the results may not be used in subsequent criminal proceedings"). The argument advanced in CLEAR, supra note 9 , is based on the fact that until 1969 , acts of the judicial police were considered "administrative" in nature. Id. at 30 . Now, "it may be said that any activity connected with criminal justice will be considered judicial [and hence subject to nullification] if it is part of one or another of the phases of a criminal proceeding and has an effect on the outcome of a case or results in coercive interference with rights of person or property," $i d$. at 38 . The argument has not yet been reflected in practice, except to a limited degree in the context of confessions and admissions of an accused.

48. Offenses under German law have been described as follows:

There is a tripartite differentiation of offenses in German criminal law, for while the traditional translations have been petty misdemeanor (Ubertretungen, punishable by short jail terms and limited fines), gross misdemeanor (Vergehen, punishable in some instancese [sic] by jail terms from one day up to five years) and felony (Verbrechen, punishable by jail terms over one year up to 15 years); in view of the severity of punishment possible for Vergehen, the analogy is not completely accurate, and the terms "petty offense" and "minor crime" for Ubertretungen and Vergehen, respectively, have occasionally been employed.

Jescheck, supra note 8, at 513 n.14 (translator's note).

49. The German magistrate (the Ermitllungsrichter), whose responsibility is to issue arrest and search warrants, is virtually an American-style magistrate. For a brief description of the currents that led to the change, see Ploscove, supra note 21, at 1035 . Writing in 1935, he said:

Since the juge d'instruction is so dependent upon the police and since impartiality cannot be expected from him simply by entitling him a judge, many German writers 
These procedures are meant to enable the prosecutor and the magistrate to retain control of investigation, but in most cases the occasion for supervision does not arise. A study of 5500 cases found that in only forty-one percent of Verbrechen and twenty-eight percent of Vergehen did the prosecutor perform an official act of investigation. And many of his actions in the investigations of Verbrechen were motions for arrest warrants, which the police must ask the prosecutor to file even after an arrest has already been made. ${ }^{50}$

As in France and Italy, warrants are usually not sought by the police. The authorization to arrest without a warrant-where there is "danger in delay" or where a person is caught in the act of committing an offense-is broad enough to serve most law enforcement purposes, particularly when little or no judicial inquiry is made into the legality of arrests. ${ }^{.1}$ In those instances in which an arrested person is brought before the magistrate, he does not look back at the grounds for arrest but forward to the need for further detention in order to continue the investigation. The brief period of detention between what may have been an invalid arrest and the appearance before a magistrate is treated as an inconvenience that the accused must suffer in the public interest. ${ }^{52}$ Warrants are used more often for searches, but search without

ask why the prosecuting attorney should not himself be required to prepare the case for trial without the intervention of a juge d'instruction.

Id. (footnote omitted). According to those we interviewed, even before the abolition of the examining magistrate, the number of cases in which he conducted an examination was very small. Where there is "danger in delay," a prosecutor may issue a search warrant on his own authority. GerMan CoDe, supra note 8 , $\$ 105(\mathrm{I})$. The German magistrate may, on occasion, conduct an interrogation of the accused or may examine a witness, during the investigation stage. When he does so, he acts at the request of the prosecutor, because records of judicial interrogation and examination can often be read into evidence at trial, while statements to the police can ordinarily be proved only by the testimony of police officers. Stepan, Possible Lessons From Continental Criminal Procedure, in THE EcoNomics of Crime and Punishment 181, 187 (S. Rottenberg ed. 1972).

The prosecutor may himself summon a witness to give evidence during an investigation (and may delegate that power to the police), but he may not take such testimony under oath. German Code, supra note $8, \$ \$ 161,163 a(\mathrm{III})$.

50. There were 2035 Vergehen and 3465 Verbrechen among the cases studied. The results of the study, conducted under the auspices of the Max Planck Institute of Foreign and Comparative Criminal Law, Freiburg, Federal Republic of Germany, are reported in E. Blankenburg, K. Sessar \& W. Steffen, Die Stadtsanwaltschaft in Prozess Sozialer KoNTROLLE (forthcoming).

51. The provisions permitting warrantless arrests appear in GERMAN CODE, supra note $8, \$ \$ 127-129$. Those dealing with orders to arrest are in id. $\$ \$ 112-114$. Robinson reports that "the order to arrest is usually issued after the man is brought in, not before." A warrant is obtained before the arrest only "when either the police or the prosecutor desires to shift the responsibility for apprehension to the judge . . . either because the case has special political import or because it is not clear that there is a basis for arrest." Robinson, Arrest, Prosecution and Police Power in the Federal Republic of Germany, 4 DuQ. L. REv. 225, 232-33 (1965) (footnote omitted).

52. One of the persons interviewed reported that the police frequently arrest a suspect for investigative purposes-interrogation, fingerprinting, etc,-and release him without 
a warrant is unquestionably the dominant mode. Most searches are made with consent or incident to an arrest. ${ }^{53}$ When the magistrate does enter the picture, either in reviewing a police request for a warrant or in considering a seizure resulting from a search without a warrant, he does not inquire into the factual basis for the police action. If the papers presented to him comply with formal statutory requirements, he routinely gives his approval.

There is in Germany even less basis than in France or Italy for judicial "nullification" of illegal acts committed during a police investigation because there are no comparable "nullity" provisions in the German Code. With rare exceptions all evidence is admissible at trial if it has probative value, even if the methods by which it was obtained were illegal. ${ }^{54}$ A statement given during illegal detention may be used against an accused unless it was "coerced," in which case it will be excluded because it is unreliable, not because it was illegally obtained. Officials point to civil and criminal actions as the means to redress grievances against the police, but few such actions are brought, and they are not likely to be successful..$^{5 j}$

In Germany, the elimination of the examining magistrate has meant that judges can supervise pretrial investigation only if police and

formally requesting the prosecutor to ask the magistrate to authorize further detention. In such situations, neither the prosecutor nor the magistrate enters the picture. The suspect is relieved to be free and usually makes no complaint.

53. For the provisions relating to search and arrest warrants, sec GERMAN Code, supra note $8, \$ \$ 102-110$. Though they do not dispute the general picture presented in the text, prosecutors and judges complained that the German police are too reluctant to search without a warrant and that valuable evidence is sometimes lost in the delay caused by seeking unnecessary judicial authorization. Robinson, supra note 51, at 280, 283 (street searches incident to arrest are rare). According to others interviewed, however, when a suspect is arrested, his house may be searched, and the period of his detention may be tied to the time necessary to complete the scarch.

54. Clemens, The Exclusionary Rule: Germany, 52 J. Crim. L.C. \& P.S. 277, 277 (1961) [hercinafter citcd as Exclusionary Rule]; Clemens, Police Interrogation Privileges and Limitations: Germany, 52 J. CRIM. L.C. \& P.S. 59, 62 (1961). There are, however, specific provisions providing for cxclusion from evidence of statements of the accused obtained by designated coercive means, e.g., torture, deception, hypnosis. Geraran Code, supra note $8, \$ 136 a$ (III). See also Kunert, supra note 7 , at $150-51$ (advocating exclusion of statements taken without warning accused of his rights "to respond to the accusation, or not to answer regarding the charge, and at all times . . . to consult with defense counsel of his choice" " (quoting $\$ 136$ (a)(III) of German Code)).

55. On the available civil and criminal remedies, see Clemens, Exclusionary Rule, supra note 54, at $281 \&$ n.31. An exception to the more common observation that criminal remedics are rarely invoked stccessfully came from an Augsburg police official who reported that twenty investigations were opened against police officials in 1975 . Ten resulted in indictments and four in convictions-three for injuries sustained by the victim and one for illegal deprivation of freedom. As in France, see note 36 supra, a defendant in Germany who is detained prior to trial and subsequently acquitted, or whose case is dismissed before trial, may receive compensation for the "unlawful" imprisonment, without regard to the legality of the arrest. 
prosecutor adhere strictly to the Code. If the police report all crimes and turn regularly to the prosecutor for investigative aid so that he, in turn, may seek judicial approval for arrest, search, and interrogation, then prosecutor and magistrate will be able to supervise at least the coercive aspects of the investigation. If first the prosecutor and then the trial judge review the dossier to be sure that legal requirementsprocedural and substantive-have been met, there is some possibility of genuine "legal" and judicial control. But as we have seen, the mechanisms of avoidance are plain; they are easily used by the police; and they are not balanced by compensatory remedies elsewhere. As a result, pretrial investigation follows Code requirements only as much as the police choose to adhere to them. They take their force through the degree of obligation felt by the police to follow legal rules, rather than through on-the-spot judicial supervision or after-the-fact remedies for breach of the Code.

The typical Western European case has not been carefully investigated by a judicial official before trial. In Germany, the office of examining judge has been abolished. The magistrate who issues warrants to arrest and search has as passive a role in the investigation as does an American magistrate. In France and Italy, the examining magistrate actively conducts the most serious investigations but plays no part in most criminal cases. His role is significant only if the case is one of the relatively few in which the prosecutor decides that a judicial examination is necessary or appropriate, and then only if it is one of the even fewer cases in which the examining magistrate determines that his active participation is required. ${ }^{56}$

The absence of a significant judicial role in an ongoing investigation might be compensated for by judicial revierw of the case before it reaches the trial judge, but in none of the three countries do judges carefully screen dossiers earlier to assure themselves that there is enough evidence to warrant putting accused persons on trial. The German prosecutor, for example, may take a case to trial without any prior formal proceedings; there is no analogue of a preliminary hearing or a grand jury. Though the sufficiency of the evidence to support

56. In addition to the usual sensational cases- $e$.g., homicides, rapes, robberics-the examining magistrate may be used extensively by a prosecutor when he needs added investigative authority, as in white-collar crimes. In Italy, in recent years, a great deal of publicity has attended the activities of certain pretori, known as pretori d'assaulto, who have moved aggressively against environmental and white-collar crimes. The pretorc, unlike the French juge or the Italian examining magistrate, may act without a request from the public prosecutor. 
the charge may be challenged by counsel as a preliminary matter at trial, ${ }^{57}$ the judge is likely to defer his decision until testimony is actually taken, thereby blurring the distinction between the evidence necessary to support the charge and that necessary to support a conviction.

In Italy and France, too, the legal and evidentiary bases for less serious charges are rarely considered by a judge before trial. Where serious offenses are involved, the judicial role is greater. For example, if the prosecutor should request an examining magistrate to conduct an examination, the magistrate-even if his participation in the actual investigation is perfunctory-will at least be required to formulate charges based solely on the evidence produced. And in France, if the offense charged by the juge is a crime, it will receive even further judicial review. The dossier is sent to the Chamber of Accusation (a panel of appellate court judges) to determine whether an indictment should be returned and the case set for trial in the Court of Assize. ${ }^{58}$ Such proceedings are, however, surprisingly brief and exceedingly rare. Because cases are so frequently "correctionalized," including many that receive a judicial examination, only about a thousand crimes are tried each year. Almost all cases are sent by the prosecutor or examining magistrate directly to the Correctional Court, which considers the sufficiency of the evidence only when the trial is over, and then only to determine whether the evidence supports a conviction, not the charge.

In sum, the prosecutor has formal responsibility for most investigation and charging, but actual control rests with the police. Prosecutors and judges rely heavily on conclusory assertions in the police papers and rarely question the officers or call witnesses to determine whether there was a valid basis for an arrest, a search, or even a charge. The

57. Germax Code, supra note 8, $\$ \$ 199,203,204$.

58. The Chamber acts on written pleadings, or if requested by the parties, on oral pleadings. The panel has the power to order further investigation to aid in its determinations or to complete the dossier for trial, Frencu Code, supra note 10, arts. 201, 205, but in fact it almost never does so. Vouin says that the Chamber "is very often quite neglectful in discharging its role," because the primary duties of the judges assigned to the Chamber of Accusation are in the civil or criminal chambers of the Court of Appeal from which they are chosen. It "allows some cases to come before the Court of Assize without really being in a state to be tried ... [and] permits various abuses to develop unchecked during the course of the preparatory examination." Vouin, Protection of the Accuscd, supra note 11, at 24-25. But cf. Norton, supra note 34, at 165: "[T]he suspect in France is given a screening procedure which is very complete. The independent judgment of 5 people, all of them trained in the law and four of them judges, is required before the suspect is formally indicted and held for trial." Norton is referring, of course, only to the procedure for crimes and is taking the statutory provisions at face value. The relerant analogy in American criminal procedure is an indictment, which, in many states and in the federal system, must be preceded by a preliminary hearing, a grand jury hearing, and a decision by the prosecutor to sign the bill of indictment. 
overwhelming presumption is that official action has been regular and lawful. Except in the most serious or notorious cases, judges limit their role to the same reactive posture that characterizes "judicial" behavior in adversary systems. Judicial supervision of the great bulk of criminal investigations is far less effective than the theory supposes.

\section{The Analogue of the Guilty Plea: The Uncontested Trial}

In all three countries, legal theory places control of the trial firmly in the hands of the court, which may find the accused guilty of any offense arising out of the matter under investigation. The pretrial stages and the dossier serve less to narrow the case to a specific set of charges than to prepare the way for the trial court's inquiry into the entire affair. ${ }^{59}$ The objective facts are said to govern, and the inquiry is to be pursued wherever it may lead, unhampered by party control, rules of evidence, or technical issues of pleading and variance. ${ }^{60}$ Most significantly, there is no guilty plea. The court has an affirmative obligation to develop all the facts and to fit those facts to the relevant provisions of the Criminal Code. There may be no "arrangements" between prosecutor and accused and no "plea bargaining." According to Professor Jescheck, such practices "would not make much sense . . . since objective proof must still be presented to the court." 11

The reality, however, is more complex. Though the accused may not avoid a trial entirely, the nature of that trial may be affected significantly by the extent to which he cooperates. Even when discretion is not exercised openly, it may operate covertly and produce functional analogues of the guilty plea and "plea bargaining." This becomes apparent in considering how different an uncontested trial is from a contested one, and how cooperation during investigation may affect the decision to charge.

59. See Herrmann, supra note 8 , at 495 ("II]n Germany, the entire criminal transaction is presented to the court, rather than merely those elements selected by the prosecutor."); id. at $495 \mathrm{n} .150$ ("[T] $]$ he judge is not bound by the legal counts of the prosecutor's charge.")

60. For a comprehensive description of these rules that govern the trial and the argument that they make for a trial more committed than an American trial to the discovery of the truth, see Damaska, supra note 7 . Compare the role of the German judge in civil cases: "The role of the court . . . throughout the proceedings is envisioned as being both directive and protective. The court [is] conscious of a duty to strive for the right resolution of the controversy regardless of faults of advocacy." Kaplan, Civil Procedure-Reflections on the Comparison of Systems, 9 Buffalo L. Rev. 409, 411 (1960).

61. Jescheck, supra note 8, at 511. See Hammelmann, The Evidence of the Prisoner at His Trial: A Comparative Analysis, 27 CAN. B. Rev. 652, 655-56 (1949). 
The Western European trial is usually described as an active inquiry by the court into the defendant's guilt. Using a dossier that has been meticulously prepared before trial, the presiding judge questions the witnesses and the accused, without relying on the parties to develop the facts of the case. Counsel for both prosecution and defense play a distinctly secondary role, at most suggesting additional questions and making motions for additional evidence. ${ }^{62}$ Defense counsel is particularly inactive. Rarely does he conduct his own investigation in preparing for trial. Even if his client should suggest someone who he thinks will offer testimony favorable to the defense, he often passes the name on to the prosecutor or judge without even troubling first to interview the witness himself.

The judge is said to conduct a penetrating search for truth, without regard to whether the defendant has conceded his guilt. In fact, however, genuinely probing trials take place only in those few cases in which the defendant actively contests the charges against him. When there is no prodding from counsel-either because the defendant ad-

62. All Italian trials, with a few exceptions, are held before three-judge panels (Tribunale) except those conducted by the pretore, who sits alone. Country LAw STudY, supra note 9, at 16. French trials in both the Court of Assize (Cour d'assises) and the Correctional Court (Tribunal Correctionnel) have three judges, except for a limited range of offenses triable in the Correctional Court, where one judge may sit alone if the accused agrees to the procedure. In the Court of Assize, there are three judges and a jury of nine laymen. A SheEHAN, supra note 11, at 6-7. German trials have either one or three professional judges, depending on the court and the seriousness of the offense. Casper \& Zeisel, Lay Judges in the German Criminal Courts, 1 J. Legal Srud. 135, 142 (1972).

In France, the prosecutor, the defense attorney, and the civil party (if there is one) may request the trial court to ask additional questions at the end of its own examination. Until 1973, the prosecutor was authorized to "pose questions directly to the accused persons and the witnesses." FRENCH CODE, supra note 10, art. 312. Similarly, in Germany and Italy the presiding judge ordinarily examines witnesses; he may permit the prosecutor and defense attorncy to put questions. As to Germany, see GrRman Code, supra note 8, $\$ \$ 238-240$. See also Damaska, supra note 7, at $525 \mathrm{n} .38$ (noting that provision for party examination (Article 239) "has never been used in practice"). In any of the three countries, the court may refuse to allow the inquiry, either because it is irrelevant, repetitive, or privileged, or because the style of the suggested questioning is overly aggressive or abusive. At the conclusion of the testimony, the parties make closing statements in which they may urge a particular resolution of any of the factual disputes, argue for the appropriate verdict, and suggest what sentence should be given if a conviction results.

Frequent note has been taken of the effect of the dossier upon the impartiality of the presiding judge at trial. See, e.g., G. Williams, supra note 7, at 31-32:

$A$ by-product of the Continental practice is that the president cannot come into court with a perfectly open mind. Since the task of interrogation devolves upon him, he must spend as much time studying the bulky dossier as an English prosecuting counsel in getting up his instructions and proof of evidence. . . . [The procedure] creates a danger that the point of view of the prosecution will communicate itself to the judge before the case has been heard. 
mits his guilt, or simply because he does not actively contest it-the judge tends to rely greatly on the dossier, becoming captive of the myth that dossiers are the products of genuine "judicial" examinations.

Procedures exist in all three countries that allow the taking of evidence to be abbreviated where a full inquiry by the court seems unnecessary. The French Code, for example, prescribes a "principle of orality," which requires that all evidence in the Court of Assize be presented in the form of live testimony rather than written depositions from the file. But the great bulk of criminal cases is handled in the Correctional Court, where the orality principle does not apply; the presiding judge often does not call witnesses if their statements are already in the dossier. ${ }^{63}$ In Italian courts at all levels, counsel frequently agree that a witness need not appear and ask the court to read the statements taken earlier by the prosecutor or judge during the pretrial examination. In all three countries, witnesses may not be allowed to testify in the undirected narrative of which Continental jurists boast and which they contrast with the party-directed examination of adversary systems. The court often summarizes the statements in the dossier, asking little more than that witnesses confirm their accuracy. ${ }^{64}$ If there is no apparent reason for the judge to question a witness closely and if there is no encouragement from counsel or the parties for him to do so, the result is a trial that is not especially probing and is unlikely to stray far from the dossier. ${ }^{65}$ It is more a

63. Sheehan writes that the practice of not calling witnesses for whom there are written statements is limited to those whose testimony was taken by a juge, and whose probity was therefore already tested by him during the judicial examination. But he notes that even when there has been no judicial examination, the prosecutor will usually summon for trial only those witnesses whose evidence is likely to be contested. A. SHEEhAN, supra note 11 , at 74 . In the Court of Assize, the jury has no access to the dossier; all evidence, therefore, must be presented in court. As to the requirement that the judgments of the Court of Assize be based on oral evidence, see id. at 83; Kock, Introduction, in Frexch CODE, supra note 10, at 10. Compare Rosett's discussion of the Dutch trial:

The practice is to accept as sufficient proof of the charge the witness statements taken before the magistrate and police statements of witnesses when corroborated by the officer who took them. This obviates in most cases the hearing of live witnesses by the court. Instead, the proof process consists primarily of interrogating the accused and incorporating reference to the items of evidence in the dossier that contain the necessary elements of proof.

[The trial] is the occasion at which it is demonstrated that the truth has been found elsewhere by the prosecuting officials, or at least that an adequate record of such a demonstration has been made in the dossier.

Rosett, supra note 12, at 375-76 (footnote omitted).

64. Though the French Code provides that "the witnesses shall not be interrupted in their testimony," French CoDE, supra note 10, art. 331, this provision applies only to trials in the Court of Assize.

65. The "orality principle" is also applicable in Germany, except as spccified by statute. See, e.g., GERMAN CODE, supra note 8 , $\$ 251$. But Langbein says of German 
selective verification of the file than the full and independent judicial inquiry promised by inquisitorial theory.

The proceedings are even more summary when the trial is entirely uncontested and the accused is willing to cooperate in his own prosecution by confessing or by remaining silent. ${ }^{60}$ In Germany, if a defendant admits that he has committed a minor offense, he can be dealt with by a "penal order," which allows a court to convict and to impose a noncustodial sentence without any trial at all. At least one-half of all criminal cases are disposed of by this direct analogue of the American guilty plea. ${ }^{67}$ Even in more serious cases, a more subtle analogue can be perceived. The uncontested trial is brief; few witnesses are called; and the judge sees his task in calling witnesses less as developing the

prosecutors, "I have never seen the legendary sleeping prosecutor, but I have seen a prosecutor reading a novel while the court conducted the proofs." Langbein, Prosecutorial Discretion, supra note 7, at 448 . Jescheck says that many German defense attorneys are "[s]o accustomed ... to the taking of evidence by the judge, that they rely completely upon him and often fail to direct the taking of proof in the manner most favorable to their client." Jescheck, Principles of German Criminal Procedure in Comparison with Aincrican Law, 56 VA. L. Rev. 239, 249 (1970). One German defense attorney complained that after reading a dossier, a judge sometimes develops a "plan" of the trial and will resist attempts by the defense attorney to take it in other directions. While the Continental defense attorney is notorious for his inactivity both before and during trial, his reputation may be unfairly tarnished by his passixe conduct in uncontested cases-those in which an American defendant would simply tender his guilty plea.

66. See, e.g., Vouin, French Criminal Procedure, in The Accused 209, 219 (J. Coutts ed. 1966): "The examination to which the accused is subjected also leaves the accused the freedom not to reply. This examination may thus reach the point where it becomes, in fact, a monologue delivered by the presiding judge of the assize court, based on documents from the preliminary investigation."

67. This figure was suggested by several officials interviewed. Jescheck said in 1970 that penal orders accounted for $70 \%$ of the convictions in German courts. Jescheck, supra note 8 , at 516 . A penal order (Strafbefehl) may be issued only when the defendant is charged with either an Uberlretung or a Vergehen. See note 48 supra. Such an order may impose a fine, confiscation of property, withdrawal of a driver's license, or a maximum of three months in jail. If the prosecutor is satisfied of the defendant's guilt, he may send the file, along with the recommendation of a specific punishment, to the judge. If, after reviewing the file, the judge accepts the prosecutor's recommendation, the penal order is issued to the accused and-without trial-becomes binding upon him if he does not appeal from it within one week. See Herrmann, supra note 8, at 502-03; Jescheck, supra note 8, at 513-16. Requests for penal orders are routinely approved by judges; when they are not, the reason is likely to be that the judge doubts the clarity of the evidence and not that the matter is too serious for a summary process and a fine. At the time of the translation of the German Code, in 1965, a defendant could receive up to six months' imprisonment on a penal order. But since January 1975, prison may not be imposed in this manner. See Langbein, Prosecutorial Discretion, supra note 7, at 456. In France, too, there is a procedure for very minor offenses that permits a judge, after having studied the investigative report, to stipulate the fine that will be imposed if the defendant chooses not to proceed with trial. Pugh, Ruminations Re Reform of American Criminal Justice (Especially Our Guilly Plea System): Reflections Derived from a Study of the French System, 36 LA. L. Rev. 947, 969 (1976). Compare French Code, supra note 10 , arts. 524,525 . 
facts than as confirming the confession. ${ }^{68}$ In Italy, uncontested trials are commonly used to corroborate the dossier quickly rather than to test or develop the facts that it presents. And when guilt is uncontested in the French Correctional Court, the trial is reduced to a perfunctory proceeding. The prosecutor may well not call a single corroborating witness. The accused makes his statement, the lawyers their speeches, and sentencing swiftly follows. ${ }^{69}$ A French prosecutor specializing in check fraud claimed to have participated in as many as sixty cases in a three-hour sitting. While this is undoubtedly an extreme, on one occasion we witnessed six trials in half an hour. These summary trials are common, and the longer and more fully contested proceedings are correspondingly rare.

In uncontested trials, the key to the sufficiency of the evidence and accuracy of the charge lies more in the dossier than in the trial itself. Since most criminal cases receive either a perfunctory judicial examination or none at all, the sufficiency of the dossier depends not on the examining magistrate, rarely on the prosecutor, and almost always on the police. The role of the court in the uncontested Continental trial can hardly be said to compensate for the limited role played by the examining judge in the pretrial investigation. In fact, the uncontested cases most carefully tried are those that, because of their complexity or importance, have probably received a thorough judicial examination. For the rest, the simpler and more routine cases, the trial is no more painstaking a proceeding than the taking of a guilty plea in an increasing number of American jurisdictions, where the judge is not only required to assure himself that a plea of guilty is made voluntarily, but must also determine that there is a factual basis for the plea. By reviewing the prosecutor's files, questioning witnesses, or examining the de-

68. Casper and Zeisel report that cases in which the court has a full confession "require less time for trial ... . but the differences are much smaller than one would expect on the basis of American experience." Casper \& Zeisel, supra note 62, at 150. Their study indicates that a full confession usually cuts trial time in half. Id. at $152 \mathrm{n} .22$. But the finding is restricted to a sample of cases tried before panels having both lay and professional judges. In 1969 , there were only 79,000 such cases. In that same year, 388,619 trials were held before a single lay judge, whose jurisdiction is limited to less serious offenses. $I d$. at 143 . Such trials may well be shorter and, as a result, even more substantially affected by the accused's confession.

69. Though Sheehan says that "a French court will only reach its decision after an examination of all the facts regardless of the attitude of the accused," he notes that the examination will often be of "a much more cursory nature," in which leading questions and pretrial statements of witnesses will be used, A. SHEEHAN, supra note 11, at 26 (footnote omitted). He also notes that in some cases, "there are no witnesses, and the accused is questioned and the evidence evaluated on the contents of the 'dossier', the relevant parts being read aloud by the presiding judge." Id. at 29. See also id. at 196-98, 202-10; note 63 supra. 
fendant, he must conduct a brief "inquisitorial" inquiry that bears striking similarities to the uncontested Continental trial.

\section{Analogues of Plea Bargaining: Discretion and Acquiescence}

Just as the uncontested trial may be the Continental analogue of the guilty plea, so also may there be processes analogous to "plea bargaining" and "plea arrangements." Continental jurists usually take a formalistic position on this question. They deny the possibility of plea bargaining by simply noting that guilty pleas are legally impermissible. The legal and ethical norms requiring that all crimes be prosecuted and that exceptions to the rule be construed strictly are said to be so strong that prosecutors will not tell defense counsel what their clients may gain by confessing or providing evidence against others, and defense counsel are unlikely to solicit assurances that their clients' cooperation will be rewarded. According to the theory, the process is objective, inexorable, and unaffected by the posture of either party or by any agreement between them.

At first glance, officials in the Continental systems appear to operate in a manner consistent with this theory. In Italy, the norm of obligatory prosecution is sufficiently strong that defense counsel rarely seek meetings with the pretore, prosecutor, or examining judge to discuss the charges to be made or the disposition to be recommended. If they do, they are likely to confine themselves to suggesting what Code provisions are applicable to the facts uncovered or what doubts remain about the guilt of the accused. The fact that the Italian pretrial examination is conducted by officials who are members of the judiciary tends to reinforce the norm that they are not to be approached informally. In France, where prosecutorial discretion is statutorily sanctioned, the ethic of compulsory prosecution nonetheless persists; conversations between prosecutor and defense counsel take place more often than in Italy, but there is little or no talk of "trading" a confession for the reduction or "correctionalization" of the charges. In Germany, the general rule of mandatory prosecution is modified by permission to exercise discretion in limited classes of cases. But there, too, the defense attorney takes little initiative in his dealings with the prosecutor. At most, he may "feel out" the prosecutor's intentions or try to persuade him that there is not evidence sufficient to proceed. Where applicable, he might discuss the recommendation of a "penal order," or suggest a fine from which his client would not appeal. It is regarded as improper, however, to discuss the possibility that the ac- 
cused would confess or give evidence against others, and prosecutors deny that they reduce charges in exchange for cooperation. Most prosecutors and defense attorneys claimed that they would never be involved in trading immunity for information, though they conceded that the police might make "deals" with informers. ${ }^{70}$

It is difficult to tell whether the repeated affirmations of adherence to the norm of compulsory prosecution and the repeated denials of agreements between prosecutor and defense attorney reflect the underlying truth, or whether they are a product of the habit of officials to answer questions in terms of formal doctrine rather than actual practice. The remarkable brevity of uncontested trials suggests, however, that European judges and prosecutors are no more anxious than Americans to prolong their proceedings and needlessly consume valuable time and resources. The mechanisms by which such summary trials are achieved tell us a good deal about whether these systems have eliminated "bargains," "arrangements," and prosecutorial discretion. They show that law enforcement in all three countries is plainly affected by what the prosecutor or judge may do for the accused, and what he may do for them. And they demonstrate that commentators may well overstate the matter when they assert that "the continental defendant has virtually no influence on the question of which mode of factfinding will be used in his case." $i 1$ In each system, there is a pervasive exercise of discretion that results from the inevitable tension between a principle of compulsory prosecution-whether formal or informal-and the practical need for flexibility.

\section{See Jescheck, supra note 8 , at 511 .}

While most German prosecutors emphatically deny that they engage in such bargains, one prosecutor did refer to a "gray arca" where he might promise leniency, or even dismissal, for a suspect's information. However, most defense attorneys say the prosecutor has little in the way of benefits to offer to an accused. For instance, they claim no attempts are made to influence the form of the charges brought by the prosecutor or his sentencing recommendation because the judge is free to ignore them. There are occasional exceptions. For example, a Munich defense attorney said he had persuaded a prosecutor to recommend leniency in exchange for a confession and to convince the judge to accept the recommendation before trial began. Curiously, some prosecutors thought conversations about sufficiency of evidence were permissible but considered it inappropriate to discuss whether the defendant's case fell within the discretionary provisions of the German Code. Other prosccutors took the reverse position. See note 78 infra.

While German prosecutors are generally reluctant to admit that they engage in informal conversations with defense attorneys, they readily admit to such conversations with judges. The judges confirm that such conversations occur and defend them as consultations between officials who share a "judicial" perspective on the outcome of a case. Defense attorneys complain that because they are excluded from this fraternity, they are prevented from presenting their views to the judiciary in a forum available to prosecutors. Judges explain that it would be improper to discuss a pending case with defense counsel, who they assume are-unlike prosecutors-partisan.

71. Damaska, supra note 7 , at 5551 (footnote omitted). 


\section{A. Italy}

In Italy, prosecution is required whenever the evidence is sufficient to support a charge. Discretion can be exercised, therefore, only by prosecutors hiding nonevidentiary considerations behind evidentiary rubrics and by examining judges dealing in token fashion with the decision not to prosecute. ${ }^{22}$ Prosecutors admit that they avoid the requirement of mandatory prosecution by the manner in which they appraise the credibility of witnesses, weigh the evidence, and assign burdens of proof. For example, when a woman of "tarnished" reputation alleges that she was raped by an established person who has no previous record, the prosecutor may make comparative assessments of credibility and decline to proceed on the basis of insufficient evidence, even though he could easily send the case to trial. Similarly, he may conclude sooner than necessary that the evidence against a cooperative accused is incomplete, or he may decide to bring only one charge against a multiple offender or to charge a lesser offense rather than an aggravated one. The pressure to use such devices increases when the Code provides not only for mandatory prosecution but for mandatory imprisonment as well. For example, persons convicted of shoplifting in public must receive a prison sentence. To avoid so harsh a result, prosecutors routinely characterize the offense as something else, such as simple theft. Similarly, where public opinion would strongly condemn prosecution, as for abortion or for Fascist-era crimes still on the books, the prosecutor may choose not to gather the evidence that would obligate him to bring a criminal charge.

In general, the lack of authorized flexibility in the Italian Code forces the prosecutor to conceal behind evidentiary judgments and procedural devices the administrative, policy, or correctional considerations that he is formally directed to disregard. The manner in which he does so is largely within his own control because, by characterizing a serious case as uncomplicated, he can keep most matters from a judicial examination and conduct the pretrial investigation

72. Country LAw Study, supra note 9, at 7-9. See p. 257 \& note 42 supra (describing process of achiviazione and formal requirement of judicial approval of prosecutor's decision not to prosecute). There are, however, a limited number of minor offenses for which the private complainant retains the initiative (querela) of pressing the case or withdrawing it. Country Law STUdy, supra note 9, at 7-8. Compare the role of private prosecution in Germany, see Langbcin, Prosecutorial Discretion, supra note 7, at 461-63; note 80 in$f r a$, and in France, see pp. 251-52 supra; pp. 276-77 infra. On the partie civile generally, see note 31 supra. The draftsmen of the proposed Italian Code of Criminal Procedure, see note 9 supra, considered a proposal that would have authorized the victim, in a broad range of cases, to petition a judge to institute an action, which would then be investigated by an examining magistrate. Despite a good deal of support, the proposal was rejected. 
himself. The veiled manner in which the prosecutor makes these judgments has tended to push the explicit exercise of discretion back to the police stage. Italian prosecutors and judges readily concede that the police do not report a great many crimes because they are too petty and that the police engage in something approximating "bargaining" with offenders in return for information or cooperation. ${ }^{73}$

\section{B. Germany}

The German Code imposes an obligation of compulsory prosecution only for serious crimes (Verbrechen). ${ }^{74}$ The lesser Vergehen may be dealt with more flexibly, in accordance with a series of statutory criteria for the exercise of discretion. To an American, it seems inevitable that prosecutors would often characterize major offenses as Vergehen in order to accomplish a variety of objectives. We have already seen such a process at work in the French practice of "correctionalization." $\pi$ s German prosecutors, however, assert that they charge "on the nose" and do not exercise discretion in deciding whether to charge an offender with a Verbrechen or the lesser Vergehen. They construe the principle of legality to require that the charge be the highest that the evidence will support. Special considerations-a confession, cooperation, the personal circumstances of the offender-are said to have no bearing; they are treated as relevant only to sentencing

73. Some Italian lawyers are said to have especially good relations with prosecutors and can, therefore, achieve more for their clients. Persistent questioning reveals that such counsel sometimes discuss cases with prosecutors and that dropped or reduced charges may result. It is interesting to note that, in the CLEAR report on Germany and Italy, answers to the question whether the police may make "any promises or bargains in order to ... induce general statements [or] confessions [or to] confer immunity" are given in terms of what the law authorizes. Bargains are said to be "absolutely forbidden," promises of immunity "not authorized." "In principle, the police are not permitted to do any of these things." CLEAR, supra note 9, at 226-27. The authors do not describe the actual practice, as they often do in other parts of the volume.

74. German Code, supra note $8, \$ 152$ ("Except as otherwise provided by law, [the prosecution] is obliged to take action in case of all acts which are punishable by a court and capable of prosecution, so far as there is a sufficient factual basis.") (footnote omitted). This is the "celebrated Legalitätsprinzip of German law (literally, the legality principle; better, the rule of compulsory prosecution)." Langbein, Prosecutorial Discretion, supra note 7, at 443. Professor Langbein notes that Savigny's conception of the prosecutor as the "watchman of the law" gave the office "a curious "double character" as both an executive and a judicial office." Id. at 449 (footnote omitted). This hybrid quality is reflected in the rule of compulsory prosecution, which requires the prosecutor "to perform an executive function according to judicial standards of conduct." $I d$. at 450 . See generally note 8 supra. For the suggestion that, at least in political cases, the principle of legality may not be consistently adhered to, see Schram, The Obligation to Prosecute in West Germany, 17 AM. J. Comp. L. 627, 630 (1969).

75. The French prosecutor may lawfully elect not to charge at all, under the "cxpediency" (or "opportunity") principle, see p. 244 supra \& note 10 supra, but if he does charge, he is expected to fit the charge accurately to the facts. 
and are passed on to the court in the dossier, perhaps forming the basis of a prosecutor's sentencing recommendation.

The Code recognizes, however, that a requirement of compulsory prosecution cannot survive if it is applied to every case. The Code sets out a series of criteria for the exercise of discretion in charging Vergehen. The prosecutor may drop a case where the guilt of an accused is "minor" and there is no "public interest" in prosecuting. ${ }^{76}$ He may dismiss on condition that the offender contribute money to the victim of the crime or to charity. ${ }^{77}$ "Insignificant matters" that are part of a "single act" may be ignored if they are likely to have little effect on the eventual sentence for the principal offense. If a person commits a large number of similar but minor offenses-for example, cashing several checks with insufficient funds-fewer than all offenses may be charged. ${ }^{8}$ Prosecution may be declined if the judge would not

76. German CoDE, supra note $8, \S 153$. Although the courts must consent to decisions to drop Article 153 cases, no judicial refinement of the standards has evolved. Nor are there rules of the Ministry of Justice that offer guidance. Langbein, Prosecutorial Discretion, supra note 7 , at 461 .

77. See Langbein, Prosecutorial Discretion, supra note 7, at 460 . Enacted into law in January 1975, this practice developed informally in northern Germany and was virtually unknown in the southern part of the country. See Herrmann, supra note 8, at 489-93. $\Lambda$ scandal resulted from the abuse of the practice in Hamburg and has made prosecutors reluctant to use it. There is also widespread concern that the practice permits wealthy offenders to "buy" their way out of a prosecution. A judge suggested to us the possibility of scaling the contribution according to the financial capacity of the accused.

78. The Code allows the elimination from the charge of "insignificant matters" that are part of a "single act" if they do not affect the expected punishment. German CoDE, supra note $8, \S 154 \mathrm{a}$. But this provision is usually read to allow a minor Vergehen to be ignored if it is part of a more serious offense (e.g., to ignore the driving charge against an accused recklessly fleeing the scene of a bank robbery) rather than to permit a "lesser included" offense to be substituted for a greater charge. Article 154a is not concerned on its face with the larger problem of multiple offenses, and several persons interviewed said it would be improper to use the article to deal with the broader problem. Such a construction is thought to be inconsistent with the requirement that the offending conduct must be part of a single act in order to qualify for the exercise of discretion under Article 154a. But see Herrmann, supra note 8, at 495-96 (reporting that "single act" has been treated as "single transaction" and as authorizing only one charge to be filed in series of frauds, in writing of several bad checks, and in filing of several false tax returns). Herrmann says:

If several crimes have been committed by the same person, the prosecutor is not always required to prosecute each offense. ...

....

In cases of this kind [e.g., frauds, bad checks], a strict rule requiring careful investigation of each act would be an unreasonable burden on the prosecutor. He is therefore given discretion to prosecute only the most serious of the offenses, or to select typical samples out of a series of acts if the selected instances provide a sufficient basis for imposing adequate punishment.

The ... Rules ... encourage the prosecutor to exercise this discretionary power, particularly in voluminous or complex cases, to simplify and speed criminal proccedings .....

This discretion is often exercised, for example, in cases involving white collar 
impose sentence upon conviction-if, for example, the accused has already suffered enough to make further punishment unnecessary. ${ }^{70}$ Finally, prosecution is not mandatory for those offenses (involving minor property damage or bodily harm) that are subject to private prosecution. ${ }^{80}$ Of all cases in 1970 in which the evidence supported a charge, $12.5 \%$ were dismissed on the prosecutor's or the judge's initiative pursuant to the "minor guilt" provision, by far the most frequently invoked exception to mandatory prosecution. ${ }^{81}$ These decisions not to prosecute must be submitted for approval by the court, but rejection of a prosecutor's recommendation is rare. ${ }^{82}$ Nevertheless, prosecutors assert that they are reluctant to drop cases for "minor guilt" or on any of the other grounds authorized by the Code. They prefer to let the judge dismiss such a case after trial begins or take special circumstances into account when imposing sentence. ${ }^{83}$

The German Code is written so that prosecutors need not hide their "real" motivations, but they remain hesitant to use even the discretion authorized, or at least to do so openly. ${ }^{84}$ One reason may be that the victim may appeal the decision not to prosecute, either to the prosecutor's superior or to the court. The frequency of these appeals is not great, but the risk that they may be taken tends to reinforce the already strong inclination to err on the side of bringing the charge.

crimes. . . . In big cases the defense attorney might contact the prosecutor to dissuade him from prosecuting some of the offenses. Careful bargaining between the defense counsel and prosecutor might follow.

Id. (footnotes omitted).

79. German CODE, supra note 8 , $\$ 153 \mathrm{a}$ (discussed in Herrmann, supra note 8 , at 493-95).

80. Often these cases are left to the victim, who is told to prosecute or not, as he wishes. The prosecutor may proceed in these cases only if he finds a public interest in doing so. The prosecutors interviewed emphasized the triviality of most cases subject to private prosecution and were more concerned with avoiding prosecution. There is another group of offenses in which the prosecutor may act only on the complaint of the victim, but he need find no "public interest" in prosecution. GERMAN CodE, supra note 8, $\$ 374-378$; see Herrmann, supra note 8, at 478, 479-80; note 72 supra.

81. E. Blankenburg, K. Sessar \& W. Steffen, supra note 50. The Blankenburg study suggests a possible white-collar bias under Article 153. In cases involving less than twenty marks, only $10 \%$ of the theft cases and $8 \%$ of the burglary cases were dropped as "insignificant" minor crimes. In contrast, $37 \%$ of fraud cases and $26 \%$ of embezzlement cases were dropped for that reason. Where more than five hundred marks was involved, $11 \%$ of the fraud cases were dropped but none of the theft cases.

82. In all the "insignificant" minor crime cases in the Blankenburg study, see note 50 supra, the prosecutor's decision was approved by the court.

83. Before trial, a charge of an "insignificant" minor crime may be dropped on the initiative of the prosecutor and with the permission of the judge. If the case is dismissed on such grounds at trial the roles are reversed. German CodE, supra note $8, \S 153$.

84. Herrmann, supra note 8 , at 484 (" $[\mathrm{P}]$ rosecutors regard compulsory prosecution and restraint of discretion as overriding principles. They generally agree that they should be reluctant to exercise their discretionary power, and they abort proceedings only in really trivial cases.") (footnote omitted). 
One official, however, suggested that prosecutors sometimes conceal the actual grounds for dismissal in order to prevent appeals by victims. They do so by relying on the "minor guilt" provision alone to drop cases in which the evidence is insufficient and the guilt is "minor," thereby preventing the victim from initiating the review, to which he is entitled only if the case is dropped on evidentiary grounds. ${ }^{85}$

The suggestion that prosecutors may conceal the exercise of discretion even when it is authorized, and that they may be doing so in order to protect their decisions from judicial review, inevitably raises the question of whether they may exercise a covert discretion even more often in cases of Verbrechen, where prosecution is mandatory. Though prosecutors deny that they use evidentiary grounds to conceal policymotivated dismissals, the denials lose much of their force when we consider the large number of cases dropped for lack of evidence. In 1970, of 3.3 million reported cases, sixty-eight percent were terminated by the prosecutor on such grounds. ${ }^{80}$ Even though these figures include crimes reported to the police but not solved, they point plainly to the exercise of some charging discretion by the prosecutor. In Germany, as in Italy, discretion may perhaps be exercised by finding the evidence insufficient, by concluding too casually that witnesses are not credible, or by terminating investigations prematurely.

If, however, it is true that German prosecutors exercise no discretion in cases of Verbrechen and hesitate to use the discretion explicitly conferred upon them in other cases, the effect may be to shift charging discretion to the police. A recent study by the Max Planck Institute of Freiburg indicates that prosecutors usually accept the view of the police that a case or a charge is not worth pursuing, even where further investigation might produce both a suspect and enough evidence to support a prosecution. And the police, secure in the knowledge that they can "predict" what the prosecutor will do, often decide that the case will not be solved, that they will be unable to gather sufficient evidence against a suspect, or that the prosecutor should or will drop the prosecution for other reasons. In expectation of that outcome, they may not investigate the matter at all and will instead send the file to the prosecutor with nothing more than the complaint and an officer's brief remarks. The prosecutor routinely accepts the judg-

85. On appeals by the victim of a decision not to prosecute, see Herrmann, supra note 8, at 477; Langbein, Prosecutorial Discretion, supra note 7, at 463-65.

86. E. Blankenburg, K. Sessar \& W. Steffen, supra note 50. Herrmann cites statistics from an earlier study by the same authors showing a range in various states, of $45 \%$ to $61 \%$, for dismissals on evidentiary grounds. Herrmann, supra note 8 , at 475 n.39. See generally id. at 486-87, 504 . 
ment of the police by closing the case. The police thus satisfy their formal obligation to report all crimes while at the same time assuring that no prosecution will follow. Only if the prosecutor considers the case to be one in which the public interest is great (for example, one involving a serious assault or significant property loss) might he pass the case back to the police for an investigation. The authors of the Max Planck study, who described the police practice to us, tellingly defend it as an extralegal device to predict the result under the Code and to achieve it in a way more "economical" than is permitted by strict adherence to the requirement of mandatory prosecution..$^{87}$

\section{France}

The French prosecutor is not subject to a requirement of mandatory prosecution, no matter how serious the offense. He may rely on the "expediency" (or "opportunity") principle to dismiss a case for either evidentiary or policy reasons; he need not hide "real" reasons behind "official" ones, or even report his decision to the court. ${ }^{88}$ However, the victim may initiate his own public prosecution by filing a complaint directly with a juge d'instruction. When this occurs, the prosecutor may not withhold the case from the juge on the policy grounds that he might have relied on in making his own decision not to prosecute. If he should refuse to authorize a judicial examination on grounds of lack of evidence, the victim may petition the juge for review. ${ }^{80}$ The

87. The practice was observed during the Max Planck study, E. Blankenburg, K. Sessar \& W. STEFFEN, supra note 50 , and is reported by Dr. Klaus Sessar, one of its authors, in an unpublished paper. Even if they frequently recommended against prosecution after little or no investigation, the police routinely reported citizens' complaints to the prosecutor. According to an earlier study, more discretion was exercised by uniformed police who uncover criminal conduct themselves while on patrol, see Herrmann, supra note 8 , at 484 , but the citizen-initiated cases made up $95 \%$ of the total of reported cases. It is difficult to know whether the small proportion of police-initiated cases is the result of the fact that citizens witness (often as victims) many more crimes than the police do, or instead a product of the police exercising their de facto discretion not to prosecute in those cases in which no citizen's complaint is made.

88. See Vouin, Protection of the Accused, supra note 11, at 9 ("[T] he procureur ... is never obliged to prosecute ... This discretion entrusted to the ministere public may appear to introduce an arbitrary element into the prosecution of crimes. But we believe in France that the prosecution of crime would not be tolerable without such an arbitrary element ...."); p. 244 supra. Compare Rosett, supra note 12, at 363-65, describing the Dutch system, which recognizes the exercise of discretion by both police and prosecutor. He says prosecutors decline prosecution under the "expediency" or "opportunity" principle in about half the cases involving charges of serious crime.

89. FRENCH CODE, supra note 10, arts. 85-87. If the offense is a delit, the victim may bring the case directly to the Correctional Court. Id. art. 382. In 1970, two out of every one thousand cases in Paris were initiated by the victim acting as a civil party. A. SHEEHAN, supra note 11 , at 22 n.38. The small number may be misleading because the prosecutor may decide to initiate the case on his own if the victim seems determined to 
result is a system that makes the prosecutor's decision turn in considerable part on the victim's persistence. If there is no victim, or if the victim does not press his complaint, the offender may go unprosecuted. And if there is public support behind a policy of nonprosecution, as was true in abortion cases before the law was liberalized, a whole class of offenses may be ignored.

Despite the "expediency" principle, French prosecutors claim that they follow a principle of mandatory prosecution as strict as that of the Italian Code. They insist that they do not reward confessions and cooperation with a favorable exercise of their discretion not to charge. They express suspicion of informers and hostility toward bargaining and profess to leave considerations of mercy to the courts. ${ }^{90}$ The system gives them the authority but not the inclination to drop the cases of helpful offenders; historic deference to the judge predisposes prosecutors to send cases on for trial and whatever amelioration the court may provide. As we have already seen, however, there are countervailing tendencies. The French prosecutor regularly uses the process of "correctionalization" to reduce the grade of an offense in order to avoid a judicial examination and a prolonged trial. In doing so, he is, in effect, offering an accused a lesser sentence for a delit in exchange for a waiver by the accused of the full process that he would have if he were charged with a crime. And the German experience suggests that if French prosecutors are as inflexible as they claim, the French police may be exercising more discretion in charging than officials there admit.o1

By being cooperative, the accused can encourage the police or prosecutor to exercise their discretion in his favor and can make his case more susceptible to summary treatment. In a minor case in Germany,

proceed. On the other hand, victims may be unwilling to risk the damages they may have to pay, French CODE, supra note 10 , arts. 91,371 , if the accused should be acquitted in a prosecution that they begin without the prosecutor.

90. French prosecutors, though not legally bound to bring any prosecution, report that they feel obligated to prosecute police informers whose offenses come to their attention. However, they accept the need to protect informers and expect the police to keep knowledge of the informer's illegal conduct from them.

91. Shechan reports that in Paris prosecutors require the police to notify them of all offenses, whether or not the suspect is identified, but that in the provinces the police are required to report only those cases in which a suspect can be named. A. Sheerian, supra note 11 , at 33 . The offender could not be identified by the police in 134,400 of the 477,870 cases reported to Paris prosecutors in $19 \% 0$. There were 66,324 prosecutions in the remaining 343,470 cases. Though some $80 \%$ of the cases in which a suspect was identified were dropped, we are not told what proportion was dismissed on evidentiary rather than policy grounds. And 160,000 were complaints about bad checks, which prosecutors express a greater than ordinary willingness to dismiss. Id. at $42-43$. 
he can accept the imposition of a penal order, which has been described as "in some sense an offer by the prosecutor to the suspect to enter a 'guilty plea." "92 In France, he can acquiesce in "correctionalization." In Italy, he can leave matters to the prosecutor and refrain from pressing for a judicial examination. And generally, by simply offering his confession or by remaining silent in the face of accusatory evidence, he can make the most complicated case into a simple one requiring only brief investigation and a quick trial. More controversially, his cooperation may make it appear more appropriate to charge less than every offense of which he is suspected, or even to forgo the prosecution entirely. As in the United States, cooperation, or lack of resistance, facilitates the operation of the criminal justice system and permits the concentration of resources on contested matters.

Explicit arrangements along these lines are unnecessary. It is plain from our interviews that prosecutors and defense attorneys rely on a general awareness that cooperation will be rewarded with leniency and that decisions will be made benevolently for the defendant who is helpful to the state. Mutual patterns of acquiescence develop in which the accused and his counsel expect concessions, which are routinely granted by the prosecutor and the court. Prosecutors and examining magistrates may find that lengthy pretrial detention is unnecessary for an accused whose ready assistance is evidence that he will neither abscond nor interfere with the investigation of his case..$^{33}$ In return for an admission of guilt, or useful evidence against others, prosecutors may recommend suspended sentences or lenient ones, and judges may impose them. Neither Continental ideology nor Continental practice

92. Jescheck, supra note 8 , at 516 .

93. Pieck reports that in France and Germany the consequence of the accused's silence may be his detention or the prolongation of his detention pending trial. Pieck, supra note 36, at 598. Confessions are common. Casper and Zeisel, in their study of German criminal courts (which excluded the courts of the lowest level), found that a "full" confession was made in $42 \%$ of all cases and a "partial" confession in another $26 \%$. Casper \& Zeisel, supra note 62, at 146-47. Pugh says that in France confession by the accused to the police is so common that elaborate investigation is rarely necessary. Pugh, supra note 11 , at 18-19. See Anton, supra note 11, at 448. See also Rosett, supra note 12, at 363 (noting in discussion of Dutch practice that $90 \%$ of all suspects confess). Rosett writes that

There is a strong suggestion that the magistrate's detention decision is heavily influenced by the defendant's refusal to cooperate and confess. An empirical study indicated that the two grounds most often cited for imposing detention were that the case was "complicated" and the "fear of collusion." Yet every case in which an accused declines to confess becomes "complicated" since it requires substantial proof from third parties. Similarly, the fear of collusion is present only when the accused has not confessed and made a signed declaration of his guilt that leaves nothing to collude about.

Id. at 369 (footnote omitted). 
prevents such rewards. A defendant's confession and cooperation are usually taken as evidence of his remorse and rehabilitation and may be considered by the sentencing judge. All that is forbidden is that the arrangements be worked out in advance. Though there are important differences between a system that authorizes or condones plea bargains and one that allows them to operate only through tacit understandings or patterns of reciprocal expectation, the two systems are not as starkly opposed as stereotype would suggest. ${ }^{94}$

\section{Conclusion}

In the United States, we are searching for new models with which to understand and manage our criminal justice system. The adversarial model, drawn primarily from the contested trial, seems almost irrelevant since more than ninety percent of those charged with crime plead guilty. At first glance, the inquisitorial model seems to be an attractive substitute. Based on a sophisticated analysis of criminal prosecution, it assumes that police and prosecutors are inevitably made partisan by the role they play in searching out the facts of crime. Only judges can be trusted to be "neutral and detached"-hence the insistence on "judicial" police, on "judicial" examination, on a principle of compulsory prosecution or controlled discretion, and on the rejection of guilty pleas in favor of full and judicially directed inquiry at the trial of every case.

Before we embrace the inquisitorial model, however, we must ask whether it describes these Continental systems any better than the adversarial model describes our own. Our study of Western European criminal procedure gives us a substantial basis for concluding that the usual portrait of "inquisitorial" systems is overdrawn. The findings that emerge most clearly have already been signalled. Even in France and Italy, which are most explicitly "inquisitorial," a judicial investigation rarely takes place before trial. It is the prosecutor who decides whether the case will receive a judicial examination, and, in most cases, he retains the file and conducts the examination himself. When a judicial examination does take place, as in the investigation of

94. See generally Cooper, Plea-Bargaining: A Comparative Analysis, 5 N.Y.U.J. INr'L L. \& Por. 427 (1972). Compare Kaplan, supra note 60, at 415:

[I]f analysis is carried on at a sufficiently high level of abstraction, all processes for rational decisions of disputes by governmental authority will be seen to have certain broad similarities. ... [O]ne of the fascinating tasks of comparative scholarship [is] to show how procedural systems announcing similar goals came to develop their divergent procedural institutions. 
the most serious crimes, it is often little more than a limited superintendence of a police investigation. The dossier, on which the trial is based, is usually compiled by the police; only occasionally does the prosecutor or examining magistrate make an important contribution. And the contents of the dossier largely determine the charge, the course of the trial, and the sentence.

Claims that prosecutorial discretion has been eliminated, or is supervised closely, are exaggerated. Discretion is exercised in each of the systems for reasons similar to those supporting it in the United States. However much Continental writers describe their criminal statutes as narrowly drawn, the codes are sufficiently general to make it necessary for prosecutors to interpret fact and law. Fact situations lend themselves to diverse interpretations of the kind and number of offenses to charge. Compassion intrudes now and then, as do periodic law enforcement campaigns and disagreements with archaic or unpopular statutes. Decisions must be made, and when the Code-or the prevailing ideology-prevents them from being made openly, each system finds ways to mask them. French prosecutors can "correctionalize" a case, or, if the victim does not complain, they may dismiss it altogether. Italian prosecutors can find the evidence in a case insufficient for trial, though their real concern may be a matter of policy. If German prosecutors are unwilling to manipulate rules or to use the discretion they have, they can achieve the requisite flexibility by accepting the judgments about investigation and charging already made by the police. Ironically, these systemic compromises are made necessary by the very principle that they contradict. The principle of compulsory prosecution, which formally permeates the German and Italian systems, and informally the French, demands the impossible: full enforcement of the law in a time of rising crime and fierce competition for resources. Inevitably, adjustments must be made in the way in which the principle is to be applied; where formal law or ideology does not permit these adjustments, informal processes are created that do.

Even the view of Continental trials as aggressive inquiries by "inquisitorial" judges does not survive close analysis. Such trials rarely occur because most cases are not contested. The accused may have confessed and provided corroborating detail, or his crime may have been witnessed by others, or he may have been caught in the act. And these facts are known to the trial judge because they are recorded in the dossier that he reads before conducting the trial. Under such circumstances, the trial becomes little more than a ritual confirmation of the police report or the prosecutor's file. In Continental systems, as in 
ours, truth is pursued in most cases in much the same way: police gather facts, put them into a file, and through processes of acquiescence and consensus, the file and the prosecutor's characterization of it usually govern the result.

Given these findings, the role of the prosecutor takes on a new importance. By reviewing the contents of the dossier, and by determining which route the case will subsequently travel, the prosecutor is clearly more important than the judge in controlling the law enforcement process. His characterization of facts and law, the degree to which he pursues investigative leads or is content to accept what the police bring to him, the extent to which he recommends leniency for an accused who offers confession, cooperation, or contrition-these become the levers by which the rest of the process is moved. Though often characterized as a "judicial" figure in the inquisitorial tradition, the Continental prosecutor (like his American counterpart) is essentially an administrator who is relatively unsupervised by the courts.

Still, the myth of judicial control persists and has a distorting effect. By formally placing investigations in the hands of judges or prosecutors, who interpret their impartial role to be a reactive one, these Continental systems may succeed only in giving greater autonomy to the police. The very fact that the police may be free of the cumbersome regulations associated with judicial investigations encourages prosecutors to delay or omit formal examinations and examining magistrates to delegate most of their work to the police. Similarly, where the principle or practice of compulsory prosecution exists, it is inevitable that the police will exercise broad discretion in deciding which cases to begin and may deprive the prosecutor-overwhelmed by the caseload and the inflexibility of his own charging options-of the ability to monitor their decisions. Finally, in assuming that the pretrial process can effectively be put under judicial, or even prosecutorial, regulation, trial judges may place unwarranted reliance on the regularity and completeness of dossiers that are in the end no more than police files.

This attitude is reinforced by the view-common among officials as well as scholars-that "law" is exclusively concerned with formal statutory provisions and that the administration of law belongs to a lower and more flexible order of things. In the moral hierarchy of the legal order, judges do not take note of how prosecutors administer the law, and prosecutors take little interest in what the police do. These officials treat as virtually "taboo" what seems to Americans to be inevitable. The existence of any choices in charging beyond those 
provided by law is steadfastly denied. There is a marked reluctance to concede an open texture even within the authorized areas of choice. Obvious patterns of evasion, designed to introduce free play into an otherwise rigid system, are described without noting the role they play in solving systemic problems.

The consequence of such attitudes is that judges and prosecutors in these Continental systems are in fact more passive and reactive than in the United States. Trial judges depend on prosecutors or examining magistrates to take initiatives in investigating and charging, and prosecutors, though not regarding themselves as truly "judicial," accept enough of the myth to prevent themselves from adopting what they see as the partisan stance of their American counterparts. Designating them as "judicial" figures seems only to reinforce their natural inclination to be reactive to police initiatives. Paradoxically, it seems to deprive them of the aggressive, yet impartial, posture that Americans associate with the European "inquisitorial" style. Overall, the result is that both judges and prosecutors deny the choices with which they are inevitably faced, leaving the police to emerge as the dominant force in the process. ${ }^{95}$

A result of treating choice and discretion as exceptional or extralegal is that charging decisions may receive even less reasoned consideration than in the United States, with less prospect that they will soon be brought out into the open. By persisting in describing their practice as if it accorded with their theory, most Continental commentators have not yet faced up to the critical distinction between full enforcement as a "regulating ideal" and full enforcement as an actual fact. ${ }^{96}$ In the United States we have tended, until recently, to the opposite extreme, accepting prosecutorial discretion as absolute, inevitable, and ungovernable, and abandoning full enforcement even as an ideal. But the same forces that have provoked interest in Con-

95. Sessar suggests on the basis of his observations, see note 87 supra, that the principle of compulsory prosecution may have forced the German prosecutor to use a more and more summary practice of closing cases for lack of evidence and may eventually prove more arbitrary than a blanket "expediency" or "opportunity" principle, such as that applicable to the French prosecutor. See also Herrmann, stupra note 8, at 505, who acknowledges the existence of "some examples of discretionary power that are not expressly authorized by the Code of Criminal Procedure" and observes: "[i]t can be argued that the development of these exceptions indicates that the German system works effectively only because of this unofficial police and prosecutorial discretion." The periodic grants of amnesty in Italy may be traced in part to more charges being filed than the criminal justice system can handle. See N.Y. Times, July 22, 1977, at 3, col. 4 (Italy considers amnesty for 15,000 ).

96. But compare the studies described in note 50 supra. See Damaska, supra note 18, at 507-09 (discussing full enforcement as "regulating ideal"); Fletcher, The Ideology of Prosecutorial Discretion (Feb. 26, 1975) (unpublished paper delivered at Yale Law School). See generally M. Kadish \& S. KADISH, Discretion to DisobeY (1973). 
tinental procedure point towards greater efforts here to bring the law in action into line with the law on the books.

We do not yet know whether increasing judicial responsibility for investigations and trials will solve the critical problems of American criminal procedure, but we can say that it is a mistake to look uncritically to Europe for the answer. The emphasis placed by inquisitorial theory on the role of the judge, not only in supervising investigation and trial, but in carrying the ultimate responsibility for enforcing the rule of law, has great force and may even deserve emulation in the United States. But Continental experience counsels caution. There may be inherent limits to what judges can and will do. It is not true that in Western Europe judges really supervise any but the most major criminal investigations. Nor do they see to it that discretion is either abolished or tamed, that no one offers inducements that produce tacit plea bargains, or that everyone plays according to the legal rules. The problem there, as here, is how to keep police and prosecutors from escaping the legal constraints imposed upon them.

In the end, these Continental systems rely more on their ideology, and on the assumption that officials adhere to the ideology, than on detailed judicial supervision. Ideology may be a powerful force in making most officials observe the rules even when no one is watching or threatening. But ideology is by no means an inexorable force; its effect may be enhanced or defeated by myriad practical considerations-institutional, economic, and psychological. Each procedural system must search for the combination of devices that is appropriate to its situation. It may be that single-theory models-whether inquisitorial or adversarial-will not work because they are inevitably stretched beyond their capacity by the phenomena they are designed to control.

To the issues we now face in American criminal justice-the regulation of police investigation, prosecutorial discretion, and the guilty plea-the usual debate about whether an "adversarial" or "inquisitorial" system more fairly and accurately searches out the truth hardly seems relevant. That debate concerns only the relatively few cases into which each system chooses to place its full efforts. For the rest, the overwhelming number, each system of criminal justice is driven to compromise principles that are regularly vindicated only when the full process is applied. The critical questions, which have not yet been honestly faced by any of the systems, are how cases that will receive less than the full process should be chosen, and what combination of adversarial procedures and judicial initiative should constitute that summary process. 